Original Article

\title{
An ethno-botanical study of indigenous medicinal plants and their usage in rural valleys of Swabi and Hazara region of Pakistan
}

\author{
Um estudo etnobotânico de plantas medicinais indígenas e seu uso nos vales rurais da \\ região de Swabi e Hazara, no Paquistão

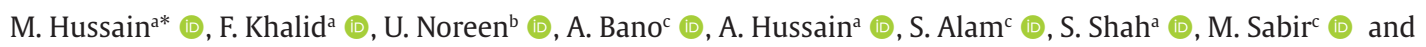 \\ U. Habiba ${ }^{\text {(D) }}$ \\ a Department of Forestry and Wildlife Management, University of Haripur, Haripur City, KP, Pakistan \\ ${ }^{\mathrm{b}}$ Department of Environmental Sciences, Abdul Wali Khan University Mardan, KP, Pakistan \\ 'Department of Microbiology, University of Haripur, Haripur City, KP, Pakistan
}

\begin{abstract}
An ethnobotanical study was conducted to document indigenous medicinal plants and their usage from knowledgeable and elderly persons in Razzar and Gadoon valley of Swabi and Allai and Tanawal valley of Hazara region of Pakistan during 2016-2019. Several systematic field visits and questionnaire surveys were carried out in selected sites of the study area to gather relevant information from the local community. Rapid assessment method was adopted for data collection by interviewing the local people having enough knowledge of medicinal plants use for treatment of different ailments. UV (UV) formula was applied to calculate the relative importance of medicinal plant species in each site of the study area. In the present study, 221 medicinal plants belonging to 105 families have been reported through 580 respondents ( 385 males, 138 females and 57 local health healer) from the Swabi and Hazara region. The main sources of herbal medicines were leaves (21\%) followed by fruits (21\%), seeds (17\%), whole plants (14\%), roots (9\%), bark (9\%), flowers (7\%) and gum (2\%). Mentha spicata L. and Berberis lycium Royle were reported with highest UV (UV) i.e. 0.92 and 0.68 in Razzar tehsil and Gadoon valley of Swabi, whereas Mentha longifolia L and Geranium wallichianum D were reported with highest UV i.e. (0.65) and (0.88) in Allai and Tanawal valley of Hazara region, respectively. It was concluded that Swabi and Hazara region is rich in medicinal plants species and associated traditional knowledge. Moreover, ethno-medicines have played significant role in the indigenous healthcare system of the study area. However, uprooting the entire plant for ethno-medicine is a big threat to conservation of medicinal plants diversity in the study area.
\end{abstract}

Keywords: medicinal plants, indigenous knowledge, ethnobotany, Swabi, Pakistan.

\begin{abstract}
Resumo
Um estudo etnobotânico foi realizado para documentar as plantas medicinais indígenas e seu uso por pessoas experientes e idosas em Razzar e Gadoon, no vale de Swabi e no vale Allai e Tanawal da região de Hazara, no Paquistão, durante 2016 a 2019. Várias visitas sistemáticas de campo e pesquisas por questionário foram realizadas em locais selecionados da área de estudo para coletar informações relevantes da comunidade local. O método de avaliação rápida foi adotado para a coleta de dados por meio de entrevistas com a população local, com conhecimento suficiente do uso de plantas medicinais para o tratamento de diferentes enfermidades. A fórmula UV (UV) foi aplicada para calcular a importância relativa das espécies de plantas medicinais em cada local da área de estudo. No presente estudo, 221 plantas medicinais pertencentes a 105 famílias foram relatadas por 580 entrevistados ( 385 homens, 138 mulheres e 57 curandeiros locais) da região de Swabi e Hazara. As principais fontes de medicamentos fitoterápicos foram folhas (21\%), seguidas de frutas (21\%), sementes (17\%), plantas inteiras (14\%), raízes (9\%), cascas (9\%), flores (7\%) e goma (2\%). Mentha spicata L. e Berberis lycium Royle foram relatados com maior UV (UV), ou seja, 0,92 e 0,68 em Razzar tehsil e vale Gadoon de Swabi, enquanto Mentha longifolia L. e Geranium wallichianum D. foram relatados com maior UV, isto é, 0,65 e 0,88 no vale Allai e Tanawal da região de Hazara, respectivamente. Concluiu-se que a região de Swabi e Hazara é rica em espécies de plantas medicinais e conhecimentos tradicionais associados. Além disso, etnomedicamentos têm desempenhado um papel significativo no sistema de saúde indígena da área de estudo. No entanto, arrancar a planta inteira para etnomedicina é uma grande ameaça à conservação da diversidade de plantas medicinais na área de estudo.
\end{abstract}

Palavras-chave: plantas medicinais, conhecimento indígena, etnobotânica, Swabi, Paquistão.

*e-mail: majid@uoh.edu.pk

Received: September 21, 2020 - Accepted: November 6, 2020 


\section{Introduction}

Ethnobotany is the systematic study of the relations among people and plants (Sheng-Ji, 2001; Dubey and Sao, 2018). For the first time in 1896, a US botanist John Harshberger coined the word 'ethnobotany', although the history of ethnobotany began long before that (Cox, 2000; Awan et al., 2013). Ethnobotany plays a crucial role in studying the effective link among biodiversity, social, and traditional systems (Panhwar and Abro, 2007; Mahmood et al., 2011a. A plant that possesses some remedial properties for healthy pharmacological effects on the human or animal body is commonly called "medicinal plant" (Ahmad et al., 2009a, b; Ahmad et al., 2010; Ullah et al., 2013). According to report of the World Health Organization (WHO) $80 \%$ of the people in developing countries depend on indigenous medicinal plants for their basic healthcare because of insufficiency or absence of modern healthcare services (Calixto, 2005; World Health Organization, 2002). The total flowering plants in the world are 422,000 (Govaerts, 2001), out of which, about 50000 flowering plants have been used for medicinal purposes globally (Hostettmann et al., 2000; Schippmann et al., 2002). More than 25\% medicines and drugs are prepared from medicinal plants globally (Malik et al., 2010). According to WHO about 252 drugs are crucial for essential healthcare and out of these $11 \%$ are obtained from medicinal plants (Rates, 2001).

People use medicinal plants for ailment treatment according to their cultural traditions and indigenous knowledge (Vandebroek and Thomas, 2003). Medicinal plants are natural asset of great significance and play a crucial role in the primary healthcare system of remote, developing and under-developed regions of the world (Shinwari and Gilani, 2003; Bhardwaj and Gakhar, 2005). For instance, medicinal plants in the Himalayas and adjoining regions (Khan et al., 2011) are the major source of ethno-medicines based on indigenous knowledge of the elderly persons (Singh and Lal, 2008). Thus, the indigenous knowledge about medicinal plants has been transmitted from generation to generation through oral conversation (Shinwari, 2010). This oral conversation although promotes transmission of indigenous knowledge about medicinal plants but also alters with the passage of time while passing from one person to another (Balick and Cox, 1996). Through ethnobotanical surveys, indigenous knowledge of medicinal plants from local elderly persons and professionals is compiled and documented in a manner to describe plants, which can be a source of medicines to cure diseases (Sarwat and Ahmad, 2012).

Pakistan has a variety of plants that are being utilized by local people as medicine to cure different ailments (Bukhari, 1994; Zandial, 1994; Pie and Manandhara, 1987; Ibrar et al., 2007; Bibi et al., 2008; Mahmood et al., 2013). According to Raj and Toppo (2014) plant diversity estimation and documentation is the first step before the second step of conservation of these natural resources. Thus, documentation is fundamental aspect for sustainability, consumption and management of medicinal flora. Many research studies have been conducted on the documentation of indigenous knowledge of native medicinal plants for healthcare purposes by the local communities of Pakistan (Shehzad and Qureshi, 2001; Saghir et al., 2001; Dar, 2003; Qureshi et al., 2007; Ajaib et al., 2010. However, there is dearth of information on ethno-medicinal uses of plants from Swabi and Hazara regions of Pakistan. Therefore, this study was conducted to explore and document indigenous knowledge of medicinal flora of selected sites of Swabi and Hazara region of Pakistan and to propose or recommend a better management and conservation plan for medicinal plant diversity in these regions.

\section{Materials and methods}

\subsection{Study Area}

The study area consists of district Swabi (Razzar and Gadoon valley) and district Hazara (Allai and Tanawal valley) regions of the Khyber Pakhtunkhwa province of Pakistan. The coordinate of Swabi is $34.1241^{\circ} \mathrm{N}, 72.4613^{\circ} \mathrm{E}$. The total area of District Swabi is $1,543 \mathrm{~km}^{2}$ (595.8 sq. mi) and it lies between the River Indus and River Kabul. The climate is sub-tropical and semi-arid and summer season is extremely hot. From May to June, temperature reaches up to $41.50{ }^{\circ} \mathrm{C}$ (Naveed et al., 2019). Winter is cold and mean monthly temperature is 4 to $10^{\circ} \mathrm{C}$. The annual rainfall varies from $60 \mathrm{~cm}$ to $145 \mathrm{~cm}$. The present study was conducted in two selected sites of district Swabi i.e. Gadoon valley, which is the only mountainous valley of district Swabi popular for Mahaban forest and Razzar which is a tehsil of district Swabi having most of the area with plain relief. Similarly, the total area of Hazara division is $18,013 \mathrm{~km}^{2}$. It lies between $33^{\circ} 44^{\prime}$ and $35^{\circ} 10^{\prime} \mathrm{N}$. and $72^{\circ} 33^{\prime}$ and $74^{\circ} 6^{\prime} \mathrm{E}$. Because of high altitude, temperature in Hazara are cooler than in the plains; though Abbottabad at 1,200 metres still has highest temperature around $32^{\circ} \mathrm{C}$ with high humidity in June and July. In winter, temperatures are cold with lowest in January around $0{ }^{\circ} \mathrm{C}$ (Ullah et al., 2019) and in minus in the higher mountainous areas of Hazara region of Pakistan. The present study was conducted in two selected sites of Hazara division, i.e. Allai valley of district Batagram and Tanawal valley of district Haripur as can be seen in Figure 1.

\subsection{Data Collection}

The data about medicinal plants were collected from selected sites of Swabi (Razzar and Gadoon valley) and Hazara (Allai and Tanawal valley) regions of Pakistan. In Tehsil Razzar of Swabi region, this research study was conducted during the year 2016-2017 and data were collected from 22 sub-sites including Karnal Sher Kalli, Sheikh Jana, Asota, Shewa, Parmoli, Ghulama, Naranji, Mehershai, Pamano Cheni, Gedare, Khalil, Sher Dara, Shera ghund, Kalu Khan, Adina, Tarakai, Rashakai, Dagai, Managi, Chaknoda, Mansabdar, and Akbar Abad. A total of 55 medicinal plants belonging to 34 families were noted for their native medicinal use. The noted plants were comprised of herbs, shrubs and trees as shown in Table 1 . Several systematic field visits were made to different locations of the study area to acquire 


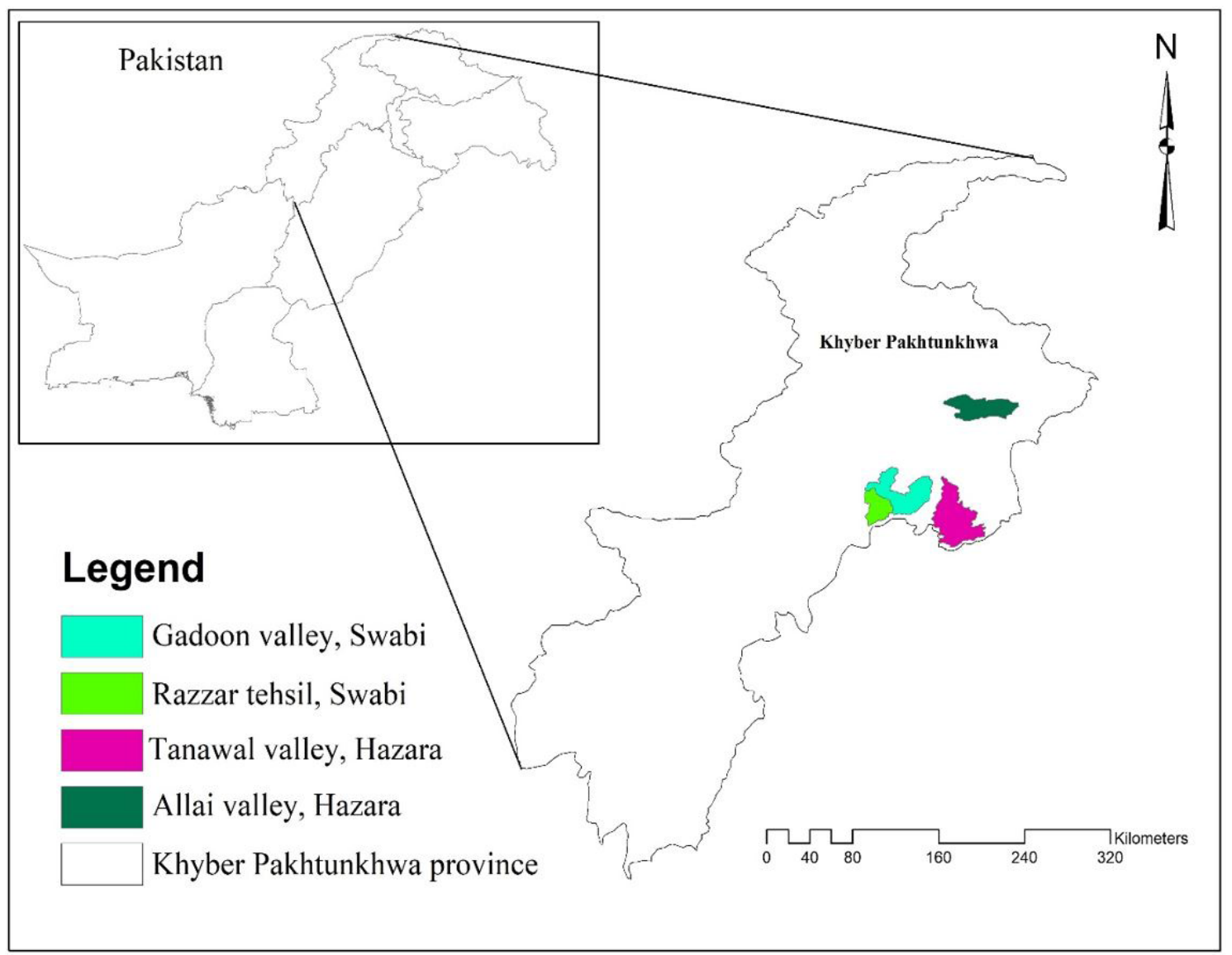

Figure 1. Location map of the study area.

information regarding parts of medicinal plants such as seeds, fruits, leaves, stem, and even whole plants used as medicine. Rapid assessment method was followed for data collection by interviewing people having enough knowledge of medicinal usages of flora in the study area. A total of 200 respondents were interviewed in the Razzar tehsil as can be seen in Figure 2. Through questionnaire surveys local name, plant parts used, remedial uses and method of preparation were documented from the elderly knowledgeable people of the study area. Similarly, in Gadoon valley of district Swabi the study was conducted in the year 2017-2018 and data were collected from 15 villages including Gandap, Chanai, Bada, Besak, Malak Abad, Kabgani, Takill, Dewal, Sandawa, Dagai, Gabasnai, Amrai, Ganichatra, Utla, and Bir Gali. A total of 57 medicinal plants belonging to 39 families were documented for their local medicinal use. A lot of regular field visits were made to the selected sub-sites to get information regarding the use of seeds, fruits, leaves, stem, and whole plants as medicine for ailment treatment in the study area. Around 150 respondents were interviewed in Gadoon valley of district Swabi (Figure 2). During questionnaire surveys local name, plant parts used, remedial uses and mode of preparation were documented from the local community of the study area. It is concluded from our questionnaire surveys that indigenous knowledge about medicinal plants and their usage was less with young generation (age limit was $<30$ ) as compare to old people (age limit was $>40$ year) because the young generation was interested in the use of pharmaceutical medicines.

Ethnobotanical surveys were also conducted in the Allai valley of district Batagram, Hazara division, Pakistan during 2018-2019. Information regarding medicinal plants was collected through field visits, personal observations and questionnaire surveys. Data was collected through random sampling in each Union Council (UC) of Allai valley. The study area was divided into different sub-sites to facilitate the data collection process. The data was collected from different sub-sites including Banna, Bateela, Koshgam, Gantar, Rashang, Biari, Karg, Rabat, Pashto, Skargah, Asharbang, Lond Khwar, Kund, Bojri and Gangwal. A total of 110 informants were interviewed during data collection (Figure 2). Likewise, the data was collected from Tanawal valley of Hazara division during 2018-2019 through questionnaire surveys to obtain information about ethnomedicines used in local healthcare system in the study area. Questions about the value or importance of medicinal plants, variety based on plants used for ethno-medicines, quantity of utilization of plants, availability, economic/ 


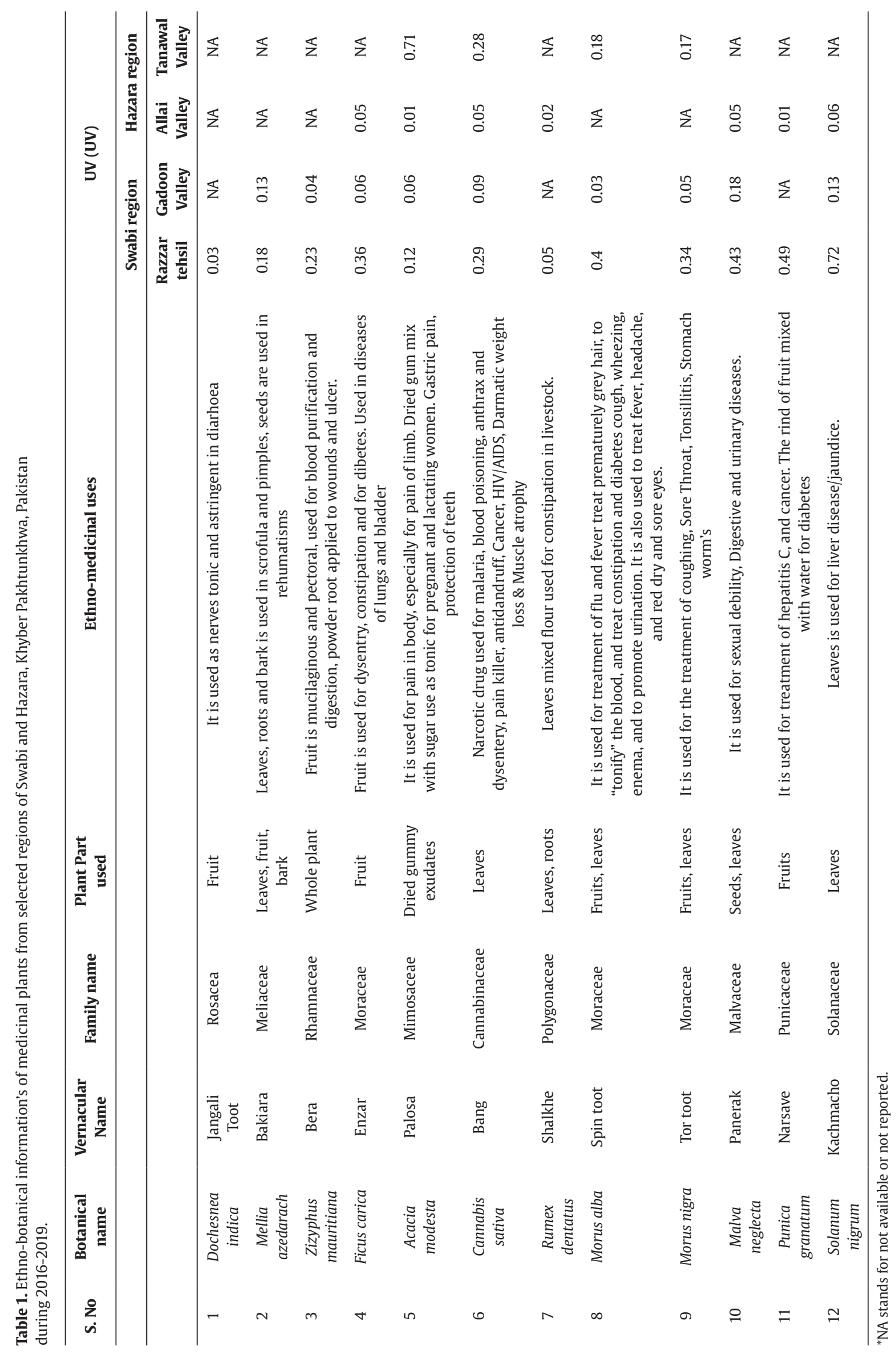




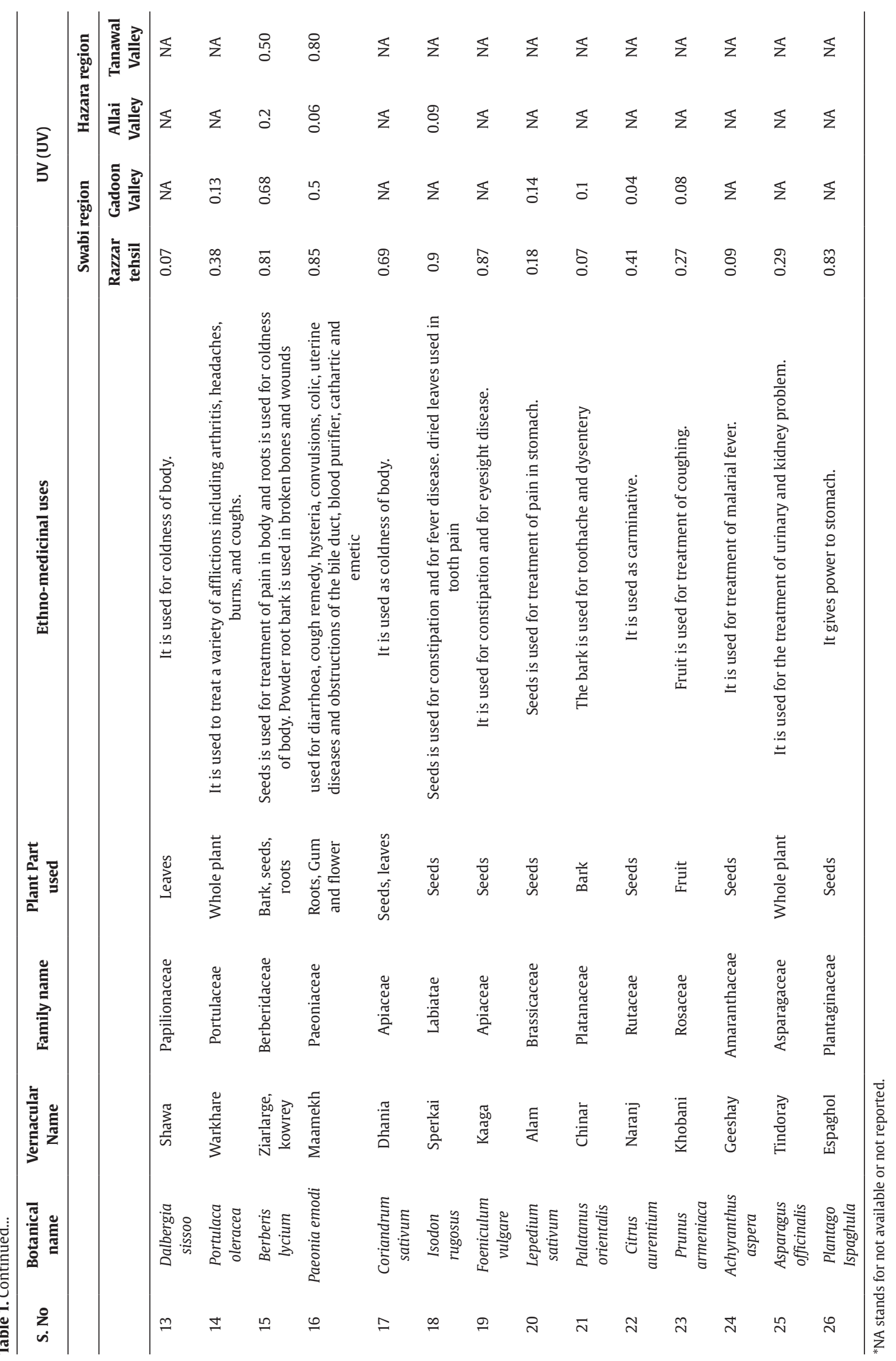




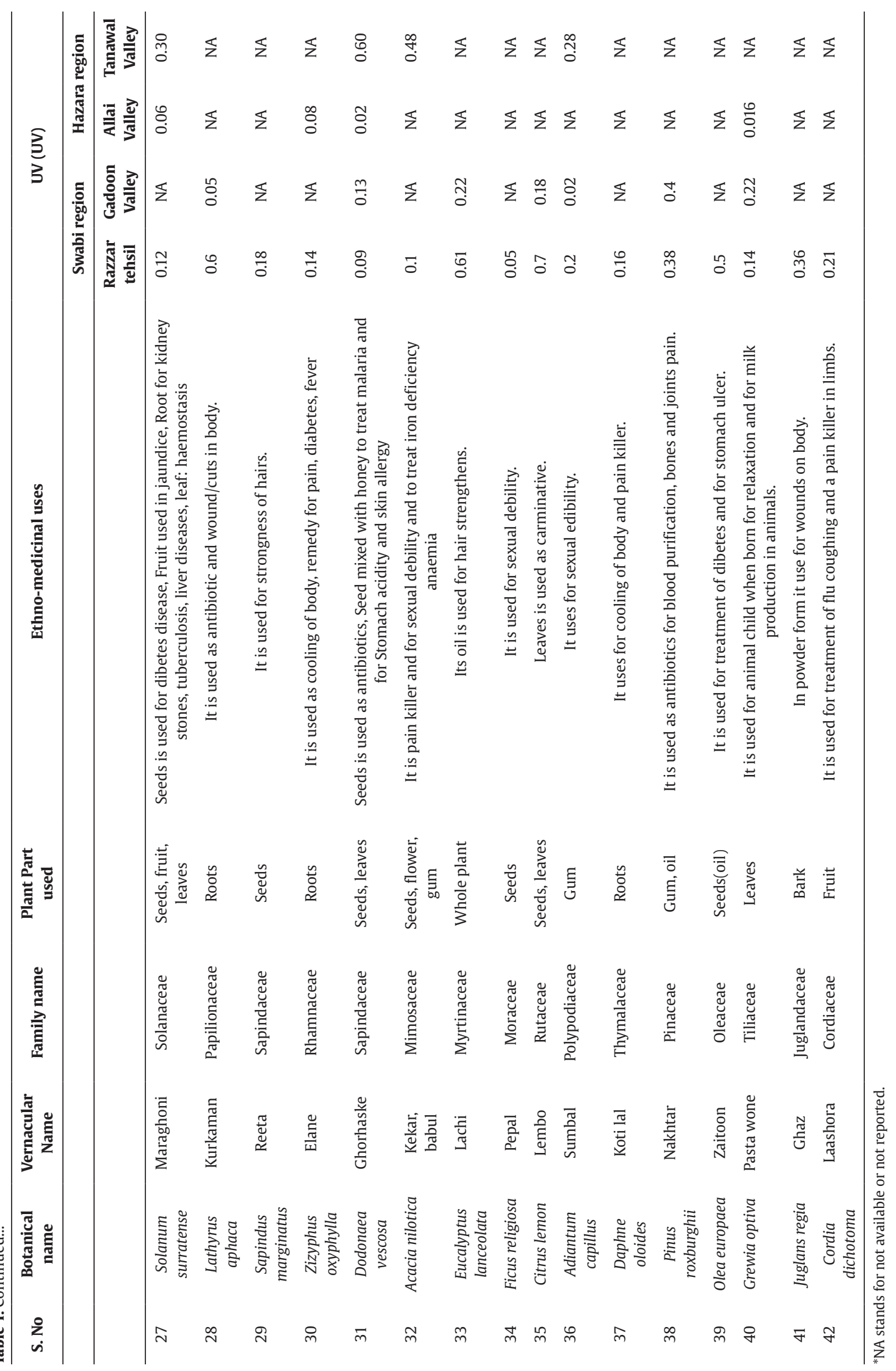




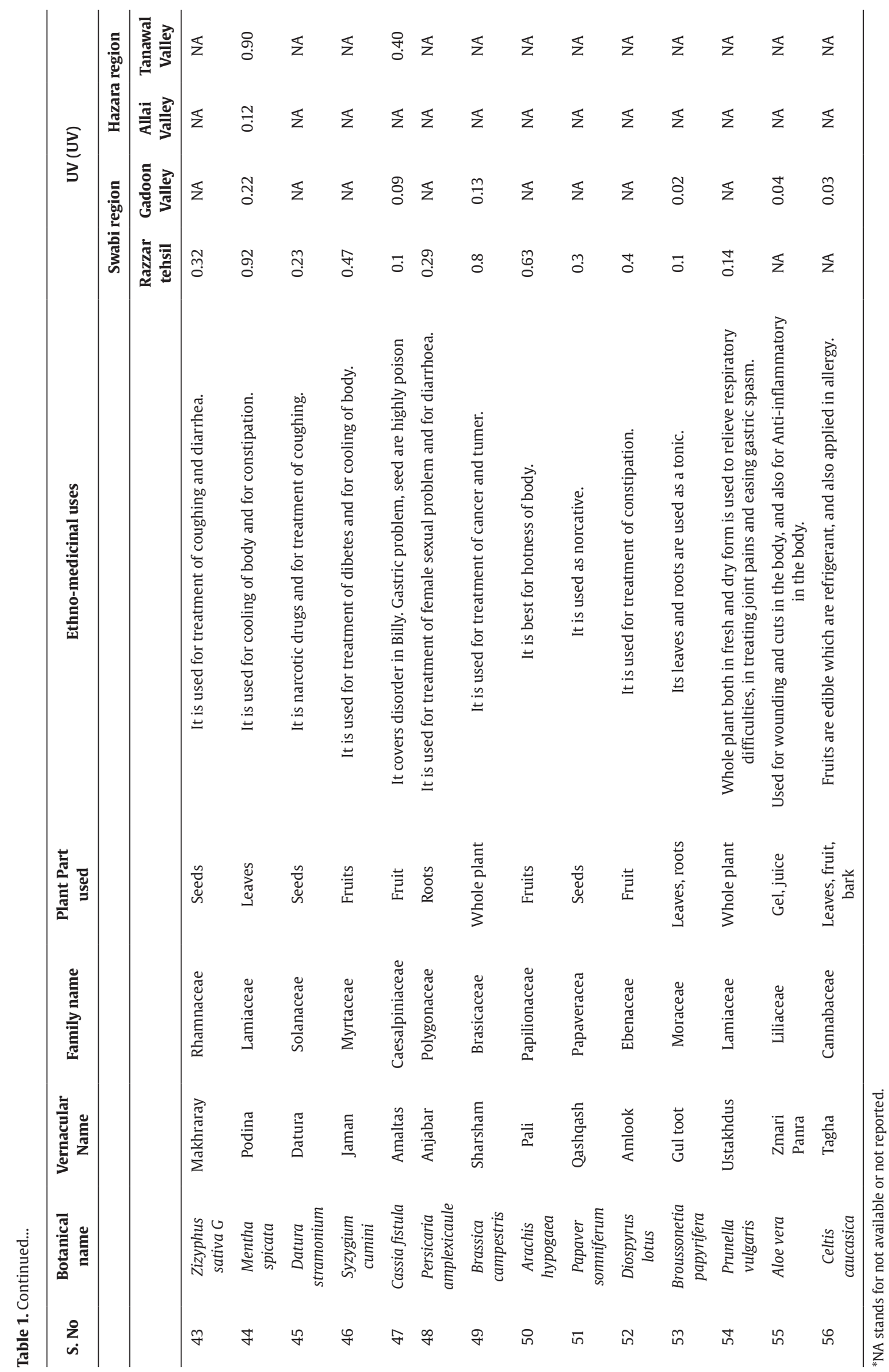




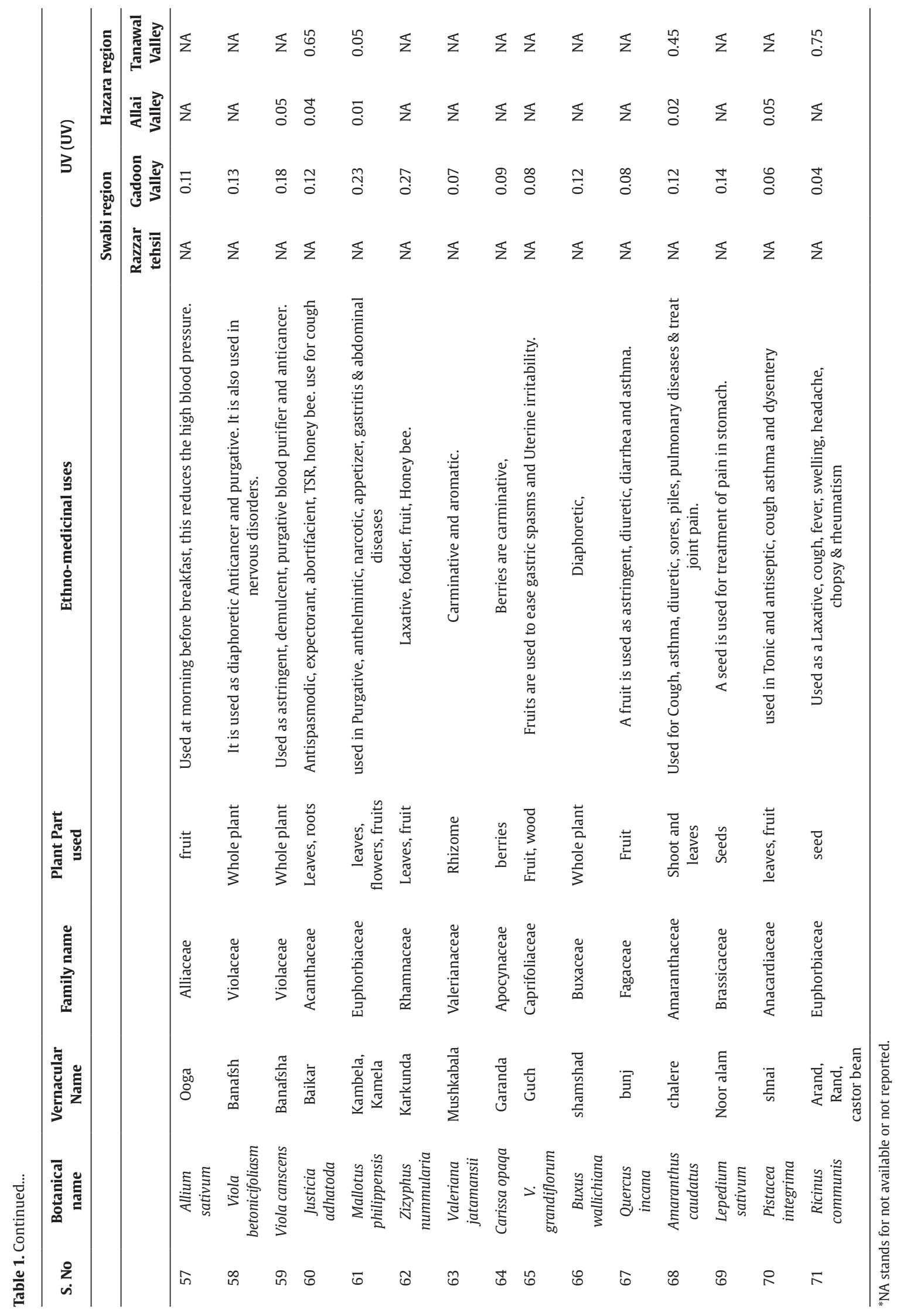




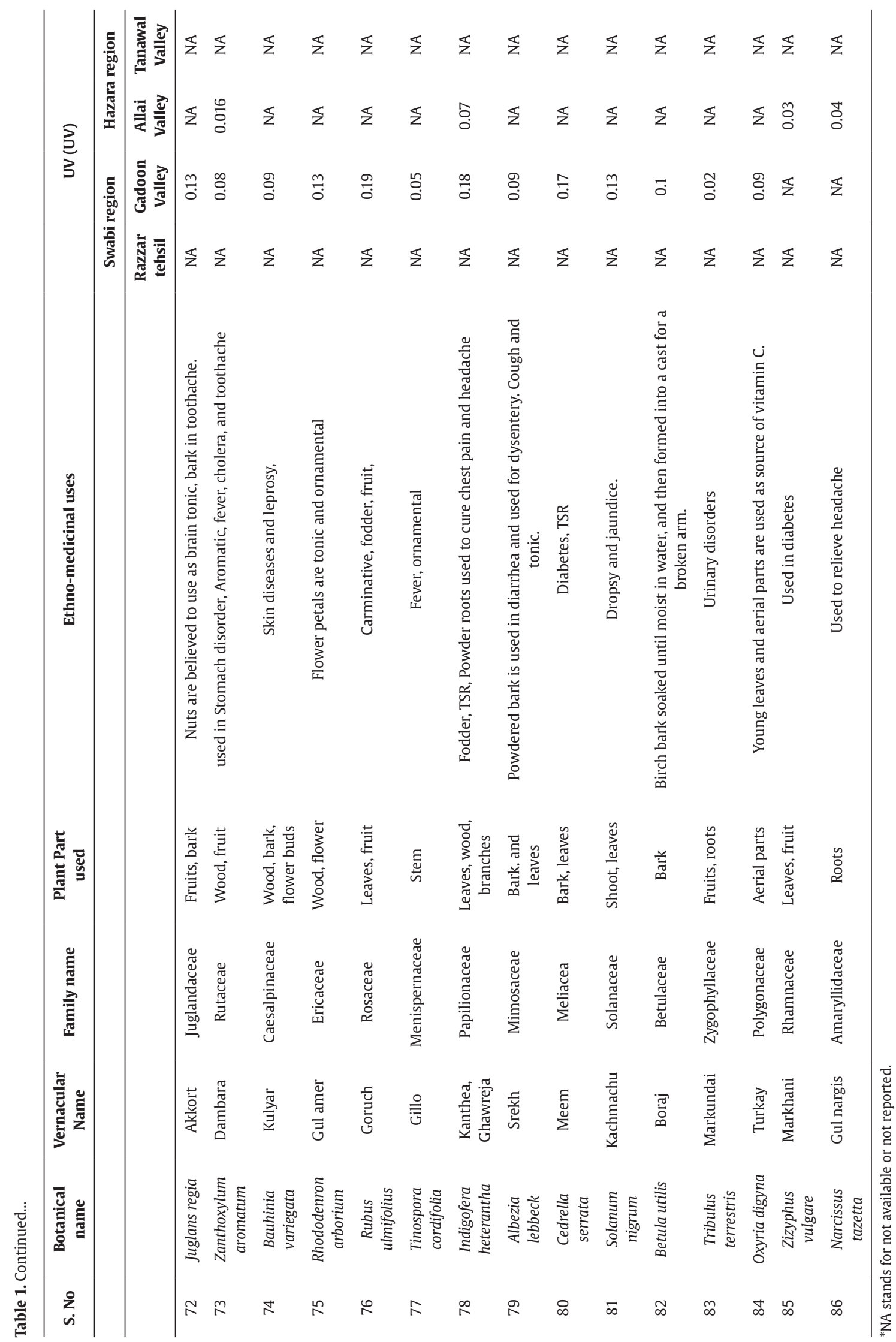




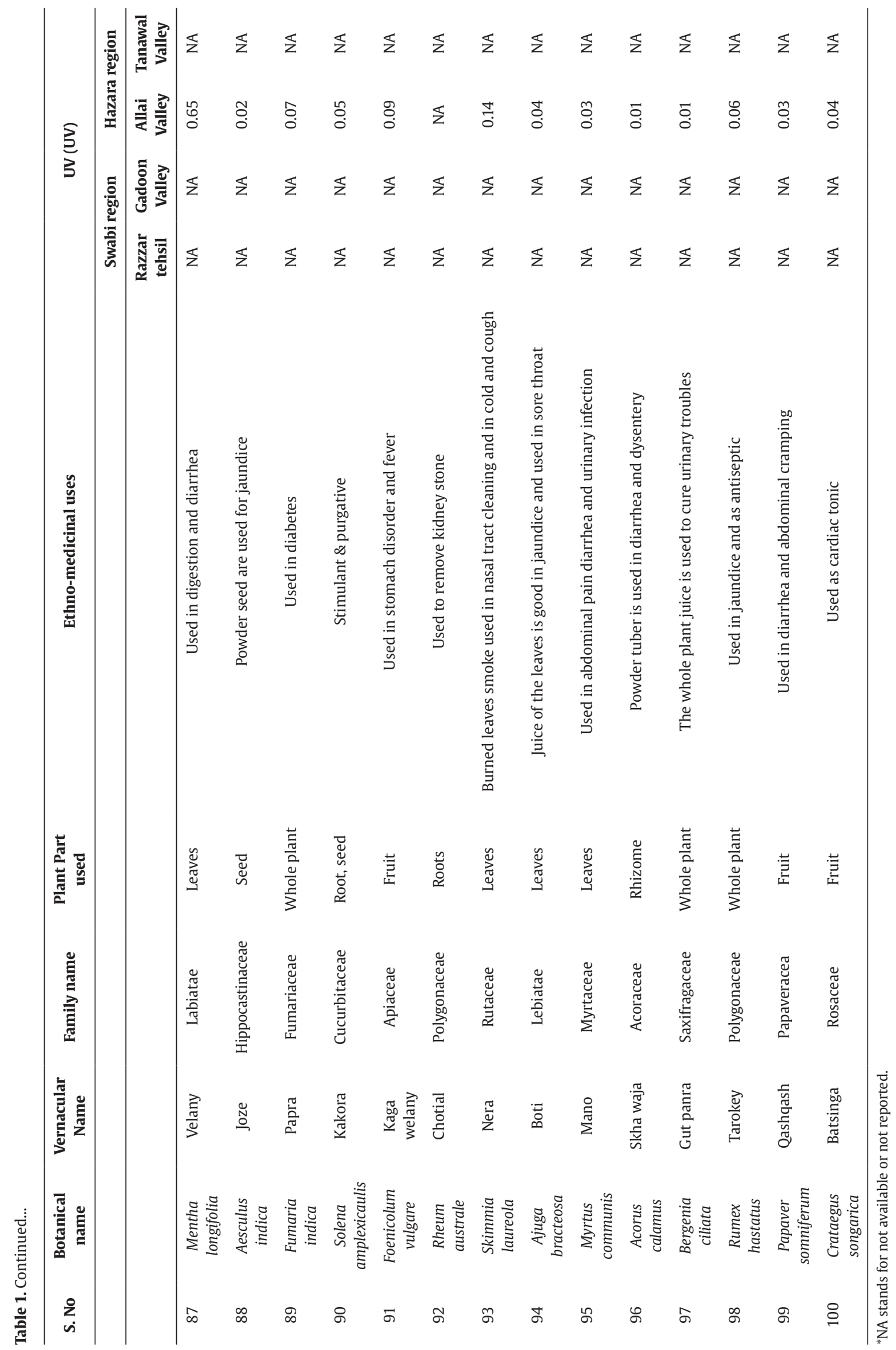




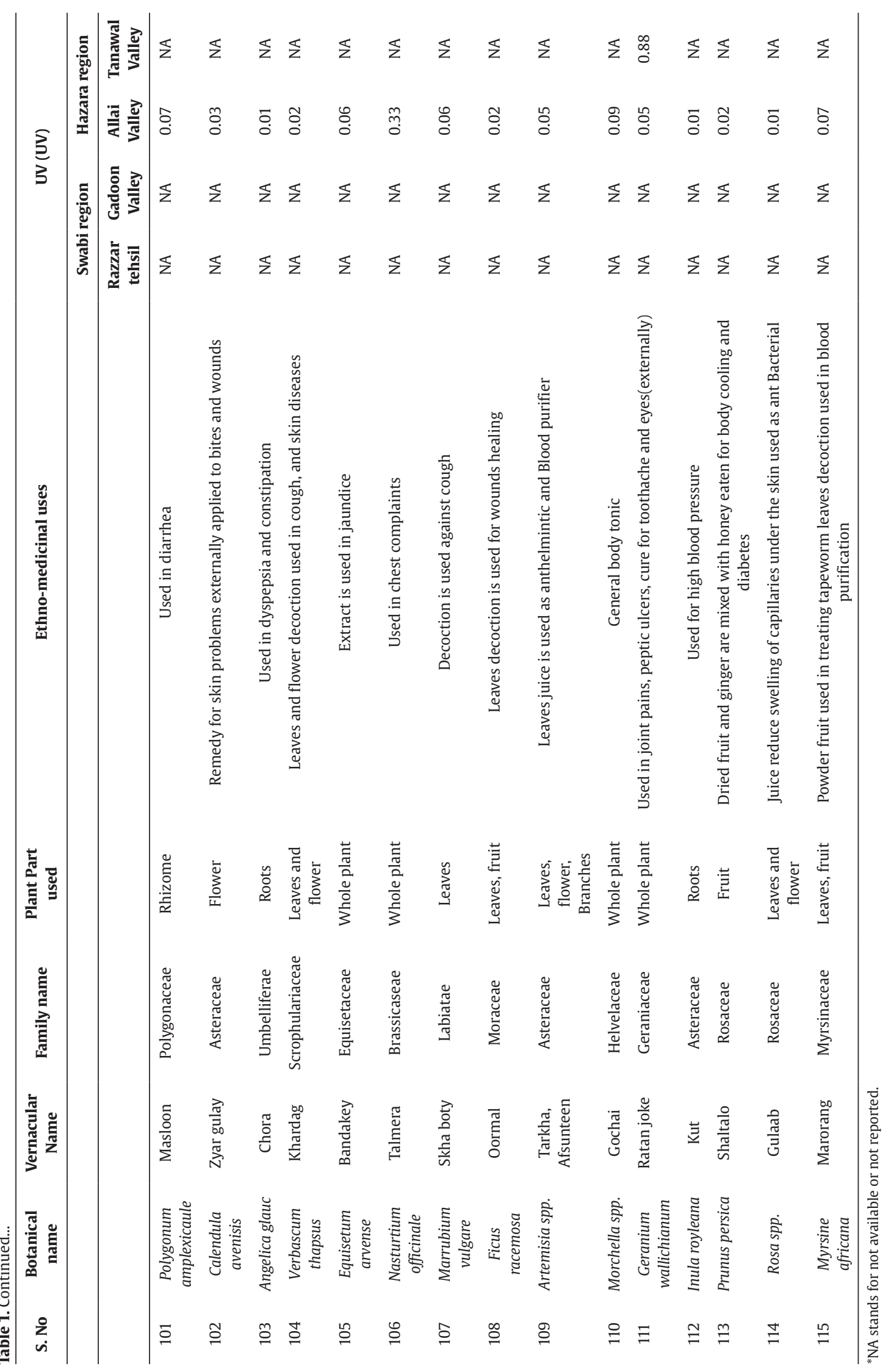




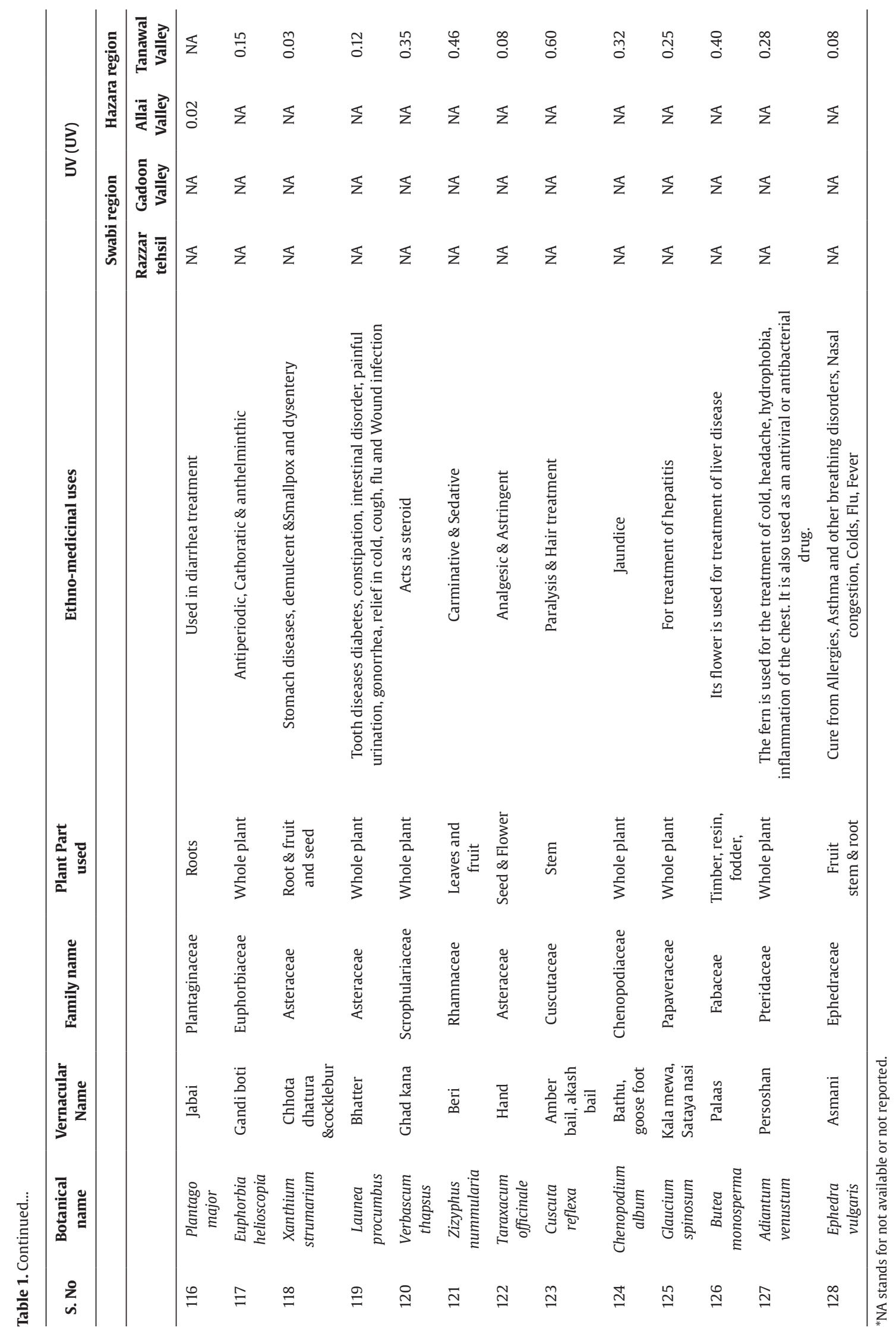




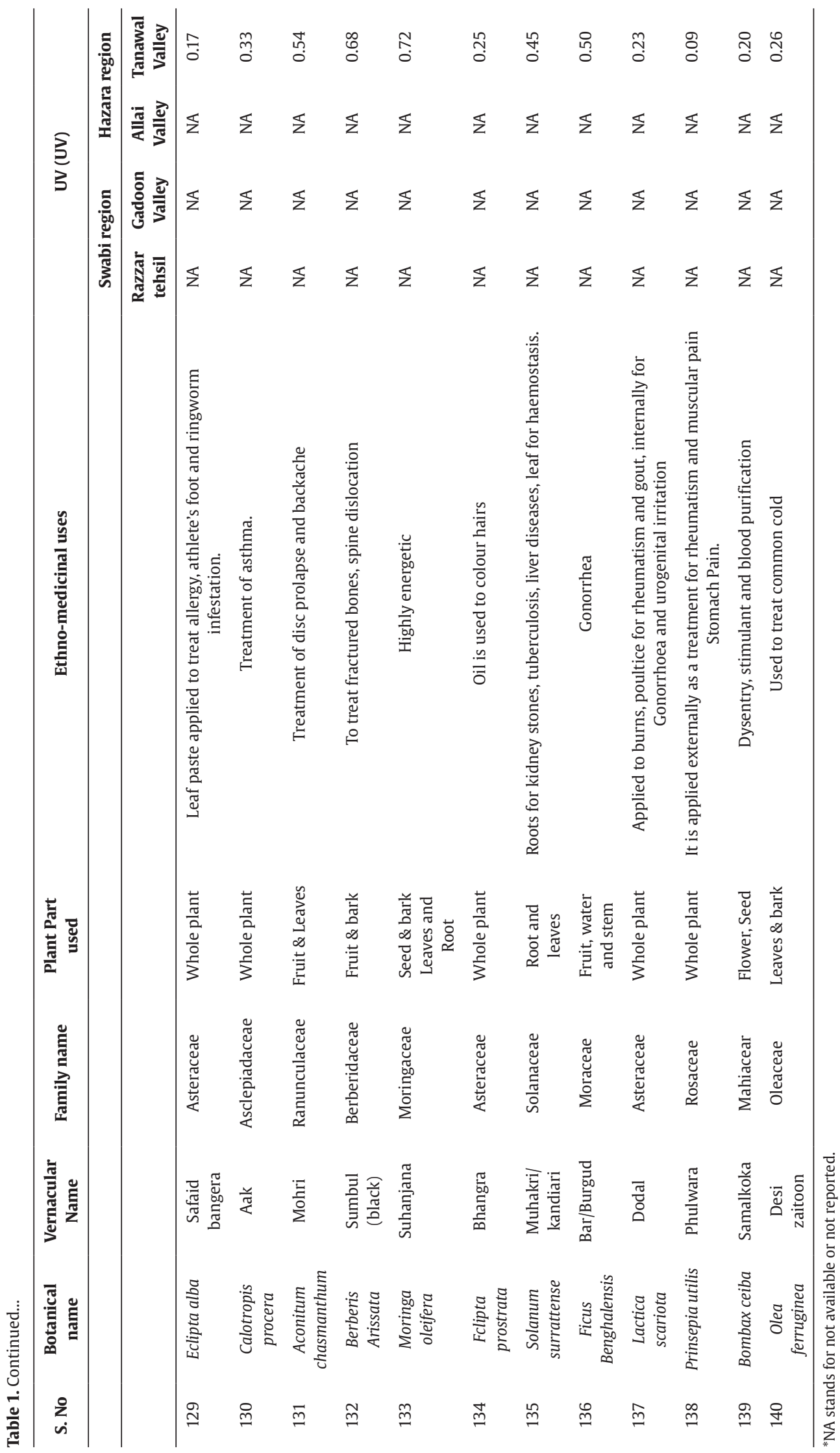




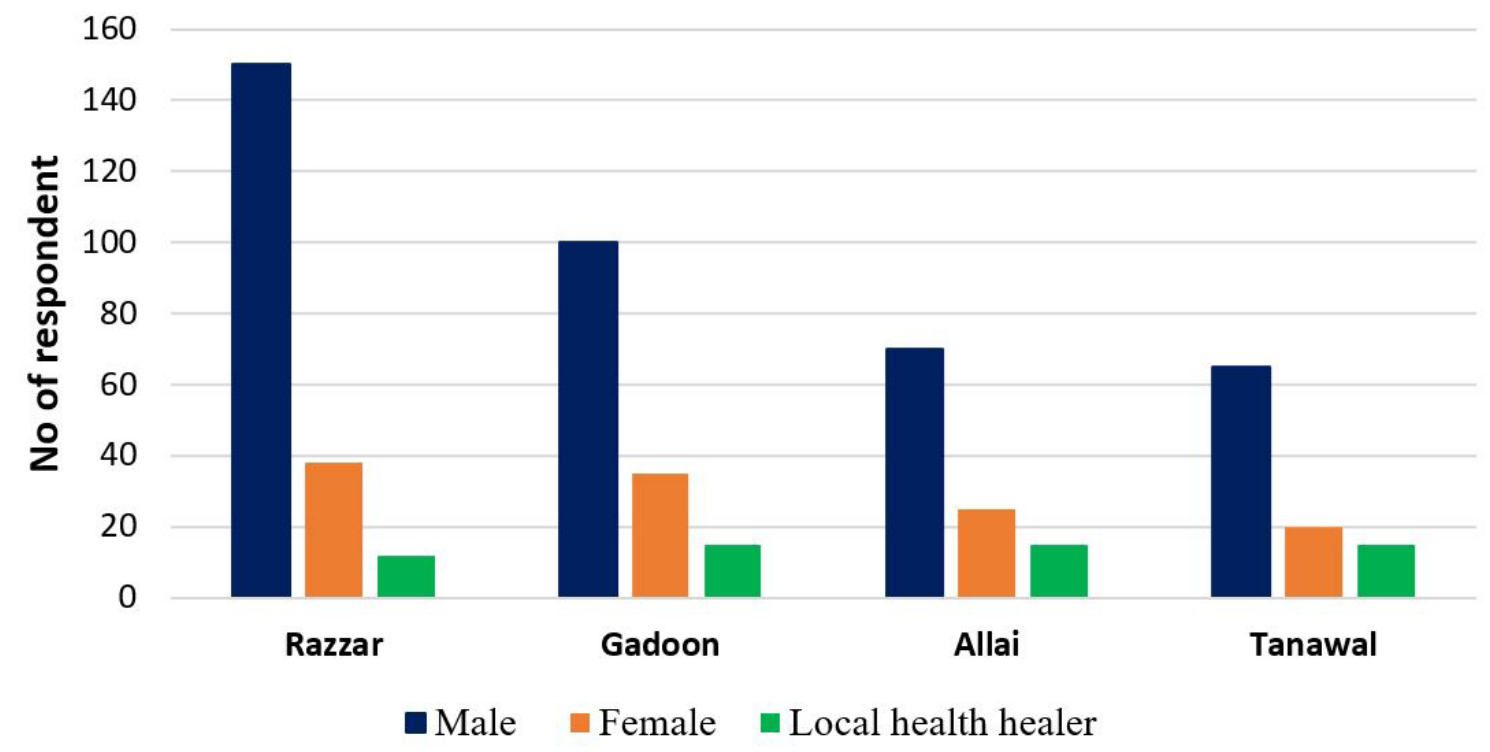

Figure 2. Gender and age character (age limit is $<30>40$ year) of peoples interviewed in the study area.

market value of medicinal plants were asked from the elderly well-informed people in the study area. A total of 150 informers were randomly interviewed as can be seen in Figure 2. The informers were comprised of male and female including the herbalists (hakims; indigenous physicians of eastern structure of healthcare system) and Pansaries (medicinal plants traders in the local market).

\section{Method Use for Data Analysis}

Phillips et al., (1994) used a formula to calculate the relative significance of medicinal plant species (Mahmood et al., 2013. The Equation 1 to determine the UV (UV) is given below.

$$
\text { UV (UV): Uvi }=\sum \mathbf{U i} / \mathbf{N i}
$$

In the above Equation 1, UVi represents UV of individual medicinal plant species, Ui represents specific plant species declared pharmaceutically important by the informers and $\mathrm{Ni}$ represents the total number of individual species interviewed or reported.

\section{Results}

\subsection{Diversity of Medicinal Plants}

The present research work was based on the ethnic knowledge of most frequently used medicinal plants in Swabi (Razzar and Gadoon) and Hazara regions (Allai and Tanawal) of Khyber Pakhtunkhwa province, Pakistan. A total of 140 medicinal plants species were reported from all the sites in the study area. The diversity of medicinal plants in Razzar region of district Swabi was identified in 2016. A total of 54 medicinal plants were identified that belong to 35 families as summarized in Table 1. Among them, 22 were herbs, 15 shrubs and 4 were found to be trees species. Five plants were representative of Moraceae family and followed by four plants of family Solanaceae, three plants each of family Rhamnaceae, Papilionaceae, two plants, each of family Rosacea, Mimosaceae, Polygonaceae, Apiaceae, Brasicaceae, Rutaceae, Sapindaceae, Lamiaceae, and one each of family Meliaceae, Cannabinaceae, Malvaceae, Punicaceae, Portulaceae, Paeoniaceae, Plantaginaceae, Palatanaceae, Amaranthaceae, Asparagaceae, Myrtinaceae, Polypodiaceae, Thymalaceae, Pinaceae, Oleaceae, Tiliaceae, Juglandaceae, Cordiaceae, Caesalpiniaceae, Papaveracea, Ebenaceae, Labiatae and Berberidaceae. Family Moraceae and Solanaceae family plants are dominantly present in the study area. Similarly, about 57 medicinal plants were identified in Gadoon valley of district Swabi belonging to 39 families as shown in Table 1. Among the families are Alliaceae, Acanthaceae, Apocynaceae, Amaranthaceae, Anacardiaceae, Berberidaceae, Brassicaceae, Buxaceae, Betulaceae, Cannabaceae, Caesalpiniaceae, Caprifoliaceae, Euphorbiaceae, Ericaceae, Fagaceae, Juglandaceae, Liliaceae, Lamiaceae, Mimosaceae, Moraceae, Meliaceae, Malvaceae, Myrsinaceae, Menispermaceae, Pinaceae, Polypodiaceae, Portulacaceae, Paeoniaceae, Papilionaceae, Plantaginaceae, Polygonaceae, Rutaceae, Rhamnaceae, Rosaceae, Sapindaceae, Tiliaceae, Violaceae, Valerianaceae, and Zygophyllaceae. Due to diversity of medicinal plants from various families Gadoon valley is recognized as one of the potential sites for medicinal plants flora in Khyber Pakhtunkhwa, Pakistan.

Various parts of different medicinal plant species were identified from Allai valley of district Batagram, Hazara region used for medicinal purposes. These include 53 ethno-botanically important species. Some of them are used individually, while other plant species are used in mixtures. These plants belong to families such as Moraceae, Mimosaceae, Cannabinaceae, Polygonaceae, 
Malvaceae, Solanaceae, Berberidaceae, Labiatae, Sapindaceae, Myrsinaceae, Rutaceae, Tiliaceae, Lamiaceae, Violaceae, Acanthaceae, Euphorbiaceae, Amaranthaceae, Anacardiaceae, Rutaceae, Polygonaceae, Acoraceae, Saxifragaceae, Papaveraceae, Rosaceae, Asteraceae, Umbelliferae, Scrophulariaceae, Equisetaceae, Brassicaceae, Helvelaceae, Geraniaceae, Rosaceae, Myrsinaceae, and Plantaginaceae. Because of medicinal plants from these families, the Allai valley has a significant diversity of medicinal flora in Hazara region, Pakistan. Likewise, a total of 40 medicinal plants were identified that belong to 24 families in Tanawal valley of district Haripur, Hazara division as can be seen in Table 1. The medicinal plants were mostly from the families i.e. Amaranthaceae, Asteraceae, Berberidaceae, Brassicaceae, Cannabaceae, Capparidaceae, Chenopodiaceae, Cupressaceae, Elaeagnaceae, Fabaceae, Juglandaceae, Lamiaceae, Moraceae, Plantaginaceae, Poaceae, Polygonaceae, Ranunculaceae, Rosaceae, Salicaceae, Tamaricaceae, Urticaceae, Zygophyllaceae, Saxifragaceae, Solanaceae. Due to variety of plant families, Tanawal valley is one of the diverse regions for medicinal plants.

\subsection{Number of informants}

A total of 200 informants ( 150 males, 38 females and 12 local health therapists) were interviewed in Razzar tehsil of district Swabi, whereas in Gadoon valley of district Swabi total of 150 informants (100 males, 35 females and 15 local health healers) were interviewed. Likewise, in Allai valley of Hazara region, a total of 110 informants ( 70 males, 25 females and 15 local health healers) were interviewed, while in Tanawal valley a total of 100 informants ( 65 males, 20 females and 15 local health healers) were interviewed as can be seen in Figure 2. During the questionnaire surveys, local name of the medicinal plant, its distribution, status, plant parts used for therapeutic purposes and threats to the medicinal plants were recorded from the inhabitants and informants of the study area.

\subsection{Plant parts used for indigenous medicines}

Plant parts used by native community to treat different ailments were mostly seeds, fruits and leaves in Razzar tehsil of district Swabi. Amongst these plant parts, seeds (29\%) were the most commonly used followed by fruits (20\%), leaves $(19 \%)$, roots $(10 \%)$, whole plant $(9 \%)$, bark (6\%), gum (6\%), and flower (1\%). Similarly, plant parts used by the local community to treat different ailments were mostly seeds, fruits and leaves in Gadoon valley of district Swabi. Amongst these plant parts, 24\% were the leaves comprising the most commonly used followed by fruits $(21 \%)$, seeds $(15 \%)$, roots $(10 \%)$, whole plant $(7 \%)$, bark (13\%), gum (4\%), flower (6\%), and leaves (11\%). In Allai valley of Hazara Division the medicinal plant parts such as leaves were highly used (28\%), followed by fruits (24\%), whole plants ( $21 \%)$, Roots ( $12 \%)$, leaves $(9 \%)$, flowers $(7 \%)$, Seeds (4\%), bark (3\%) and gum (1\%). Whereas, in Tanawal valley of Hazara division, seeds were highly used (20\%), followed by the whole plants (18\%), flowers (16\%), fruits (15\%), leaves (13\%), bark (12\%), roots (4\%) and gum (2\%) as can be seen in Figure 3.

\subsubsection{Relative Importance of medicinal plants}

To assess the relative importance of medicinal plants used in the Razzar tehsil of district Swabi use value (UV) was calculated by the formula described by Phillips et al. 1994 with minor modification. Medicinal plants used frequently exhibited higher UV as compared to the least used medicinal plants as can be seen in Table 1. Relative importance of UV showed the importance of medicinal plants in terms of their traditional use in the study area. Therefore, in Razzar tehsil of district Swabi, Mentha spicata L. exhibited the highest UV i.e. 0.92, followed by the Isodon rugosus

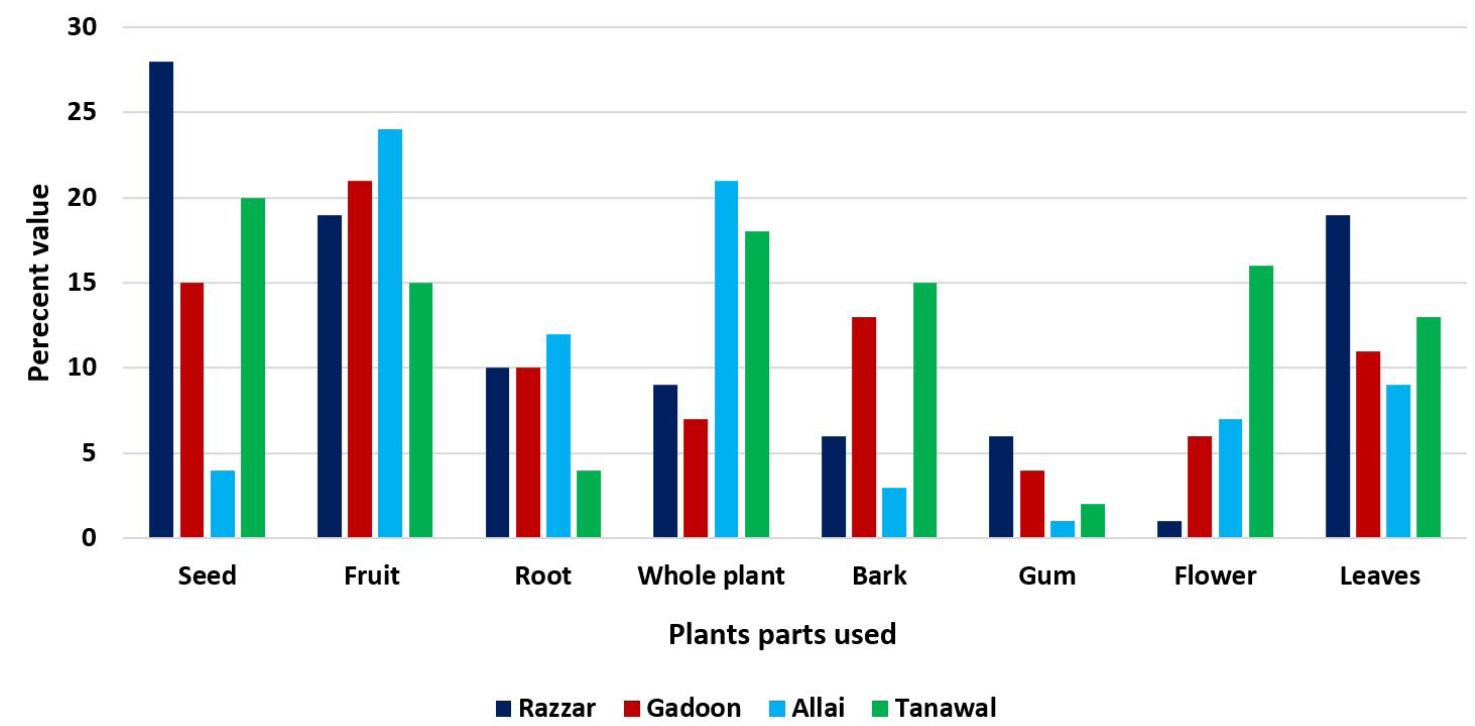

Figure 3. Plant parts used for indigenous medicines in the study area. 
L. (0.90), Solanum nigrum L. (0.89), Foeniculum vulgare M (0.87), Paeonia emodi W (0.85), Plantago Ispaghula (0.83), Berberis lycium R (0.81), Brassica campestris L. (0.80) and Solanum nigrum L. (0.72). Least UV was reported for Rumex dentatus $\mathrm{L}(0.05)$ and Dochesne indica $\mathrm{A}(0.03)$ as can be seen in Figure 4. Medicinal plants of Gadoon valley reported the highest UV for Berberis lycium R(0.68) followed by Mallotus philippensis L (0.23), Eucalyptus lanceolata M (0.22), Rubus ulmifolius S (0.19), Indigofera heterantha W
(0.18), Citrus lemon L (0.18), Lepediumsativum L (0.14), Juglans regia L (0.13), Paeonia emodi $W$. (0.5) whereas the Tribulus terrestris L. (0.02) and Celtis caucasica L (0.03), reported the least UV in Gadoon valley of district Swabi as depicted in Figure 5.

Similarly, in Hazara division the important medicinal plants species of Allai valley, district Batagram with highest UV were Mentha longifolia (0.65), followed by Nasturtium officinale W(0.33), Skimmia laureola D (0.14), Mentha spicata

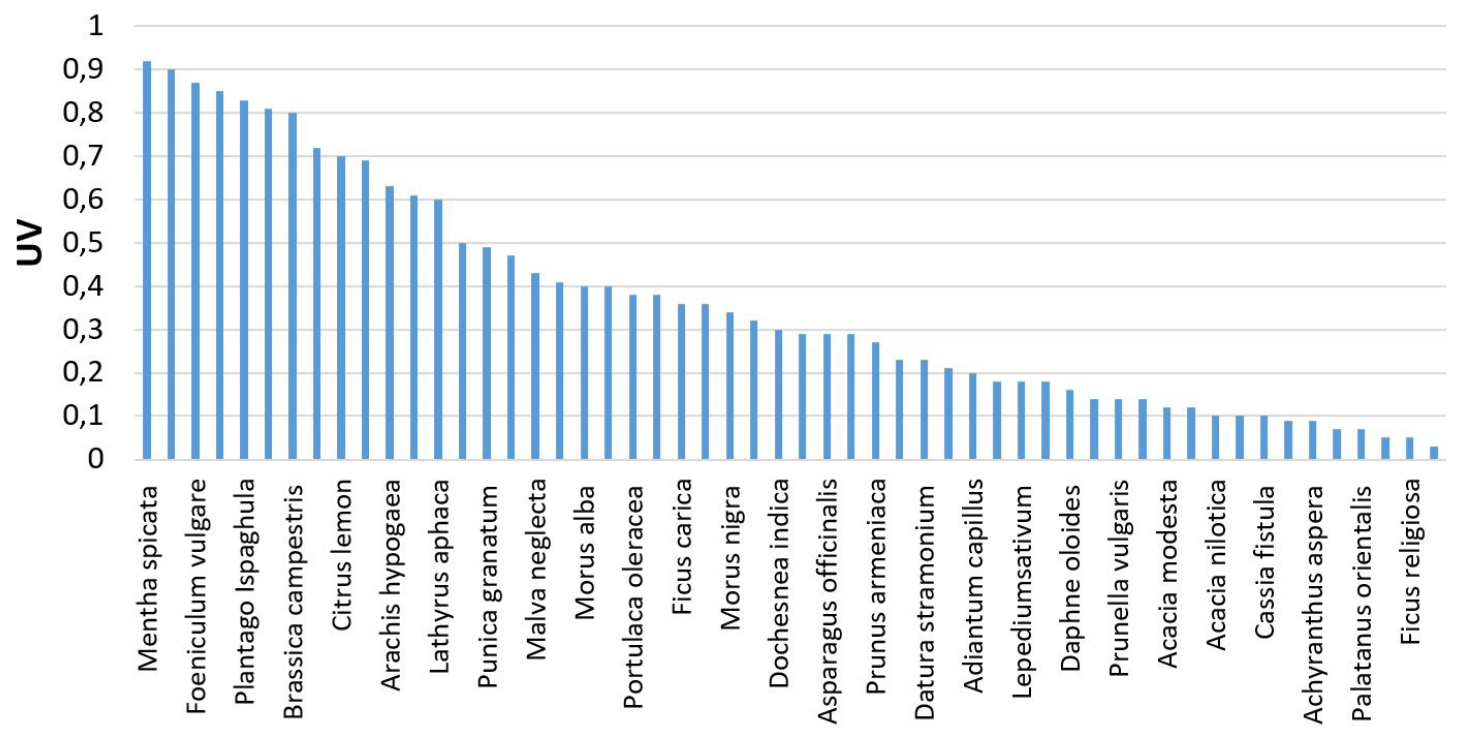

Medicinal plant species

Figure 4. Relative importance of medicinal plants based on UV in Razzar tehsil, District Swabi.

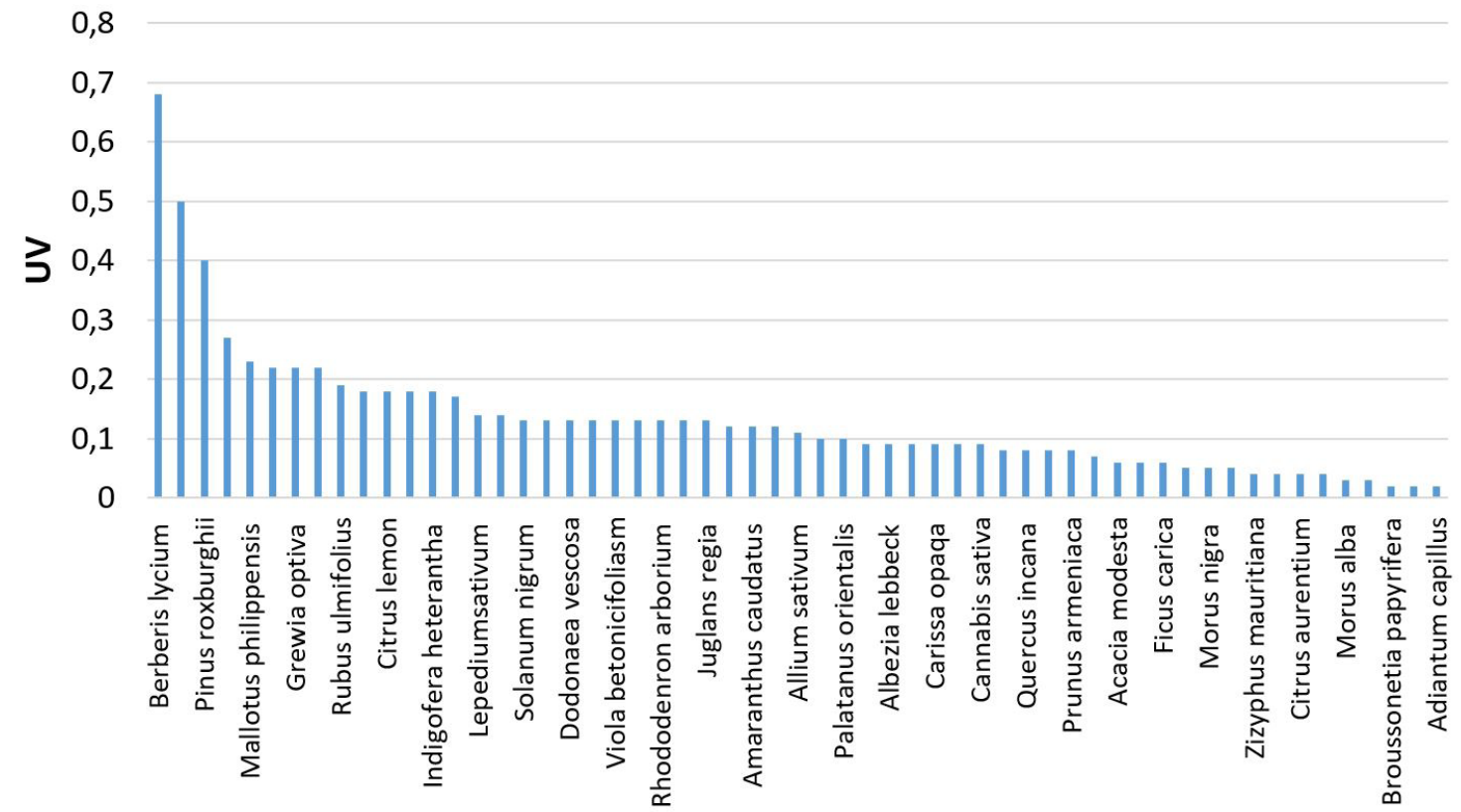

Medicinal plants species

Figure 5. Relative importance of medicinal plants based on UV in Gadoon valley, District Swabi. 
$\mathrm{L}(0.12)$, Foenicolum vulgare $\mathrm{M}(0.09)$, Morchella spp $\mathrm{L}(0.09)$, Zizyphus oxyphylla M (0.08), Polygonum amplexicaule D (0.07), Fumaria indica L (0.07), Myrsine africana L (0.07) Equisetum arvense $L(0.06)$, Solanum surratense $L(0.06)$, Marrubium vulgare $\mathrm{L}(0.06)$, and Paeonia emodi $\mathrm{W}(0.06)$ as shown in Figure 6. Likewise, medicinal plants of Tanawal valley, district Haripur reported highest UV for the Geranium wallichianum Olive (0.88), followed by Ricinus communis L (0.75), Moringa oleifera L (0.72), Berberis Arissata D (0.68), Justicia adhatoda L (0.65), Aconitum chasmanthum L (0.54), Acacia nilotica L (0.48), Zizyphus nummularia M (0.46), Amaranthus caudatus L (0.45), Verbascum thapsus L (0.35), Calotropis procera $\mathrm{A}(0.33)$, Adiantum capillus $\mathrm{L}(0.28)$ and Morus nigra L (0.17) whereas Xanthium strumarium L and Ephedra vulgaris L revealed lowest UV (0.03 and 0.08), respectively as depicted in Figure 7.

\subsection{Herbal Therapies of Indigenous Plants}

The Razzar tehsil of district Swabi is enriched with medicinal flora that are used to cure different ailments. A single disease is treated by several plants meaning more than single plant is active for different ailments' treatment in Razzar tehsil of district Swabi. More than $13 \%$ of medicinal plant species were used for the treatment of cough in Razzar tehsil, followed by constipation (12\%), analgesic (12\%), antiseptic (12\%), sexual debility (9\%), body coldness (9\%), diabetes (7\%), narcotic (7\%), fever (7\%), antibiotic (4\%), carminative (4\%), rheumatism (2\%), dysentery ( $2 \%$, stomach (3\%), hair strength (3\%), kidney problem (3\%), and cancer (1\%). Similarly, the Gadoon valley of district Swabi is also enriched with medicinal flora, which is used to treat different disorders. Medicinal plants used in treating cough are more than $18 \%$, followed by stomach (13\%), analgesic (12\%), body coldness (10\%), constipation (10\%), antiseptic (10\%), tonic (9\%), fever (7\%), wound (7\%) and diarrhoea (4\%). It was reported during the study of Allai valley in Hazara division that $14 \%$ of medicinal plants were used for treatment of cough and cold, followed by diarrhoea $12 \%$, stomach problems ( $9 \%)$, skin disease ( $7 \%$ ), external wound $(7 \%)$, diabetes $(7 \%)$, fever $(5 \%)$, urine infection (5\%), bone problems (4\%), blood problems (3\%), and $1 \%$ of plant species for kidney stone. In Tanawal valley is also much diversified in plants that are being used by the local community, herbalists and knowledgeable elderly persons to cure different diseases. Several plants in the study area treat a single disease. About $14 \%$ of medicinal plants were used for diarrhoea treatment, which is followed by toxin (8\%), diabetes (7\%), hepatitis (7\%), analgesic (6\%), narcotic (7\%), cough (7\%), fever (7\%), asthma (6\%), stomach (6\%), tonic (6\%), liver (5\%), abortification (4\%), rheumatism (4\%) and laxative (4\%) as show in the Figure 8.

Local people are well engaged in the cultivation of medicinal plants such as Mellia azedarach L, Zizyphus mauritiana L, Ficus carica L, Morus alba L, Morus nigra L, Coriandrum sativum L, Citrus aurentium L, Prunus armeniaca L, Eucalyptus lanceolata M, Citrus lemon L, Cordia dichotoma G, Zizyphus sativa L, Mentha spicata L, Syzygium cumini Diospyrus L, Berberis lycium R, Eucalyptus lanceolata M, Rubus ulmifolius S, Indigofera heterantha W, Citrus lemon L, Lepedium sativum L, Juglans regia L, Paeonia emodi W, Tribulus terrestris L, Celtis caucasica L, Moringa oleifera, Olea ferruginea, Berberis Arissata D, Justicia adhatoda L, Aconitum chasmanthum L, Acacia nilotica L, Zizyphus nummularia B, Amaranthus caudatus L, Ficus benghalensis L, Verbascum thapsus L, Calotropis P, Adiantum capillus L, Morus nigra

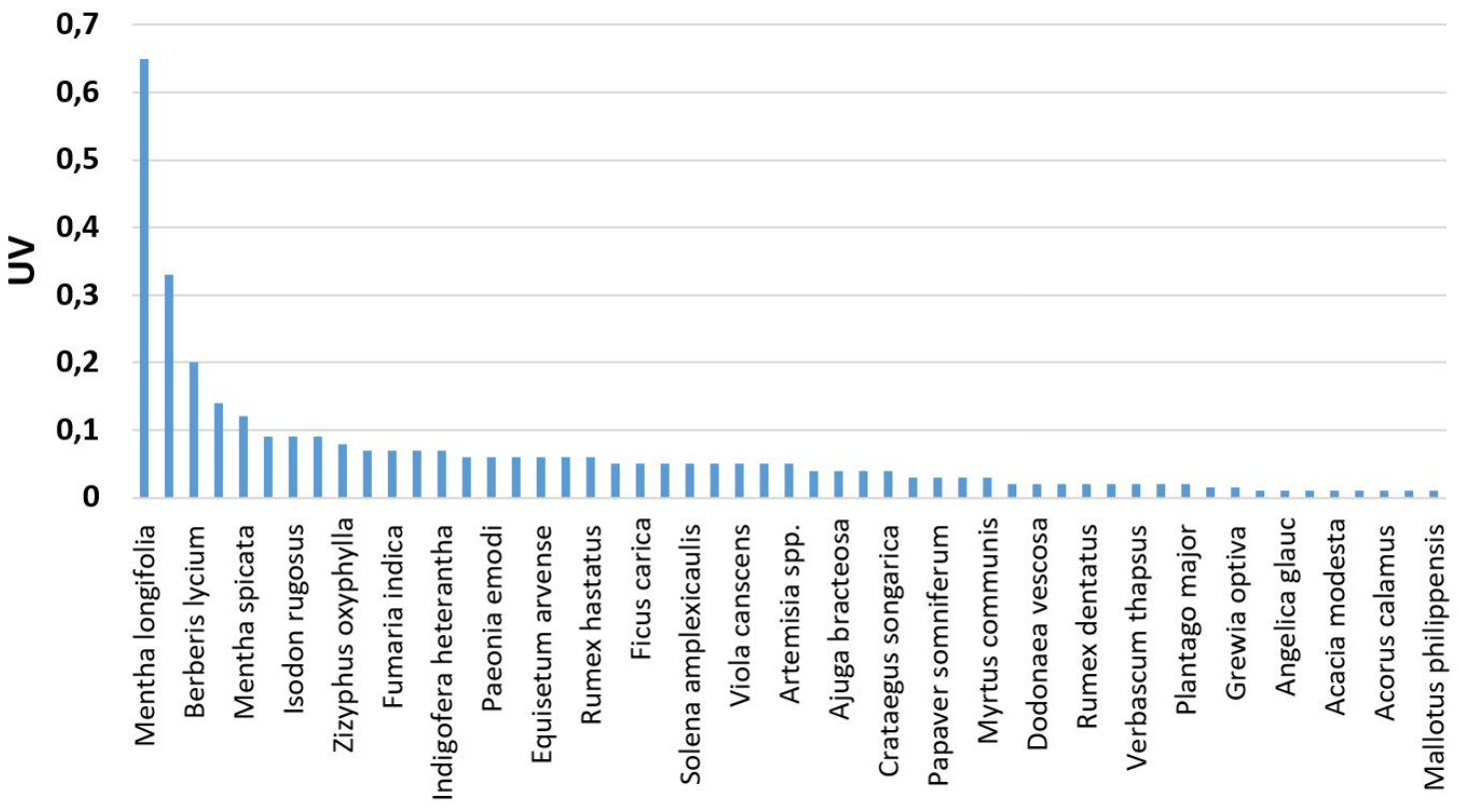

Medicinal plants species

Figure 6. Relative importance of medicinal plants based on UV in Allai valley. 


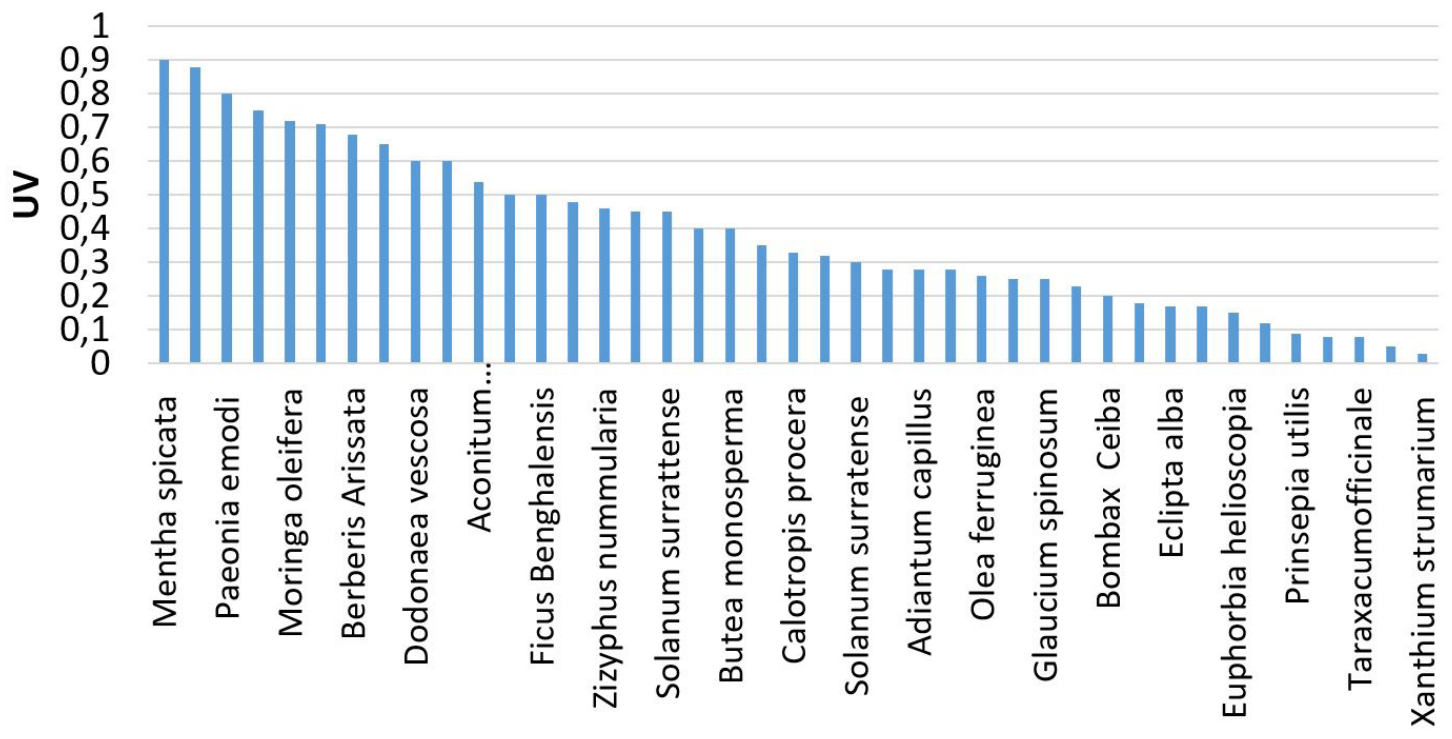

Medicinal plants species

Figure 7. Relative importance of medicinal plants based on UV in Tanawal valley.

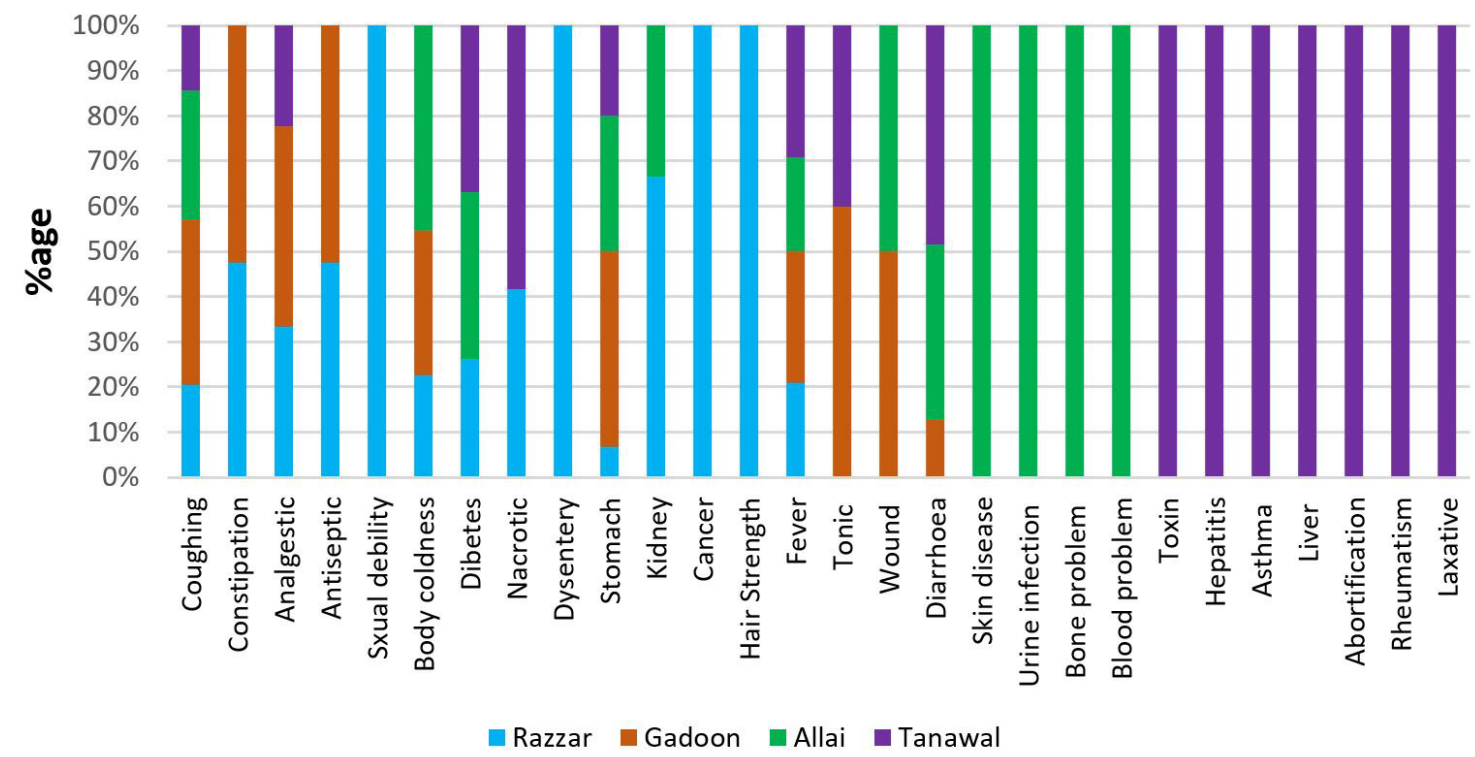

Figure 8. Herbal therapies of indigenous plants in the study area.

L, Geranium wallichiana O, Justicia adhatoda L, Aconitum chasmanthum L, Acacia nilotica L, Amaranthus caudatus L, Verbascum thapsus L, Calotropis procera A, Adiantum capillus $\mathrm{L}$ and Morus nigra L Even though medicinal plants are grown in this region, many people still purchase medicinal plants/herbs from herbal shop locally called Pansari shops or herbal stores whereas some medicinal plants are also harvested from natural forests, which could cause threats to their survival and conservation. The present study reported that more than 20 types of ailments including hepatitis, jaundice, diabetes and cardiac problems have been treated using medicinal plants, because the selected sites are remote areas of the country having diverse medicinal flora. Therefore, these medicinal plants should be focused for detail phytochemical and safety evaluations.

\section{Discussion}

Pakistan has diverse climatic parameters and its soil is rich with medicinal plants and herbs, which are growing naturally in different period of the year. In rural society of Pakistan, almost $75 \%$ of the people are still dependent on traditional medicines for their primary healthcare system 
(Ullah et al., 2013), because new amenities of modern healthcare system are not accessible and/or provided to them. Therefore, huge populations are dependent on herbal treatments and native herbalists perform a dynamic role in the healthcare system and ailment treatment of the society in the study area. Easy approachability of herbs or medicinal plants, useful treatment action and reasonable price of healthcare facility are the main factors for the advancement and preference of herbal medicines in the rural and poor communities (Konno, 2004). More than 5,700 medicinal plants are present in Pakistan, out of which, about 372 medicinal plants frequently exist and 350 formulated drugs are manufactured from those medicinal plants (Ahmad and Husain, 2008). History on this planet shows that without medicinal plants' application, human healthcare is not possible (Mahmood et al., 2011c. Therefore, it is in great benefit of the future generations and they will possibly benefit from this treasure of medicinal plants, which is a gift, and blessing of nature for humanity however, in the present period it is alarming that the understanding of ethnobotany is declining very quickly (Mahmood et al., 2011b. Therefore, present young generation does not have enough knowledge about indigenous medical plants and their mode of application for different ailments' treatment. Thus, it is very crucial to transfer this valuable ethno-botanical knowledge from the elderly and resourceful persons to the young generation and document it as well, because through proper documentation of this knowledge we will not lose this unlimited natural wealth, which is going to vanish quickly. Hence, this study provided significant information about the ethno-botanical use of medicinal plants (leaves, bark, roots, fruits, seeds, gum, etc.) in selected remote and hilly regions of Pakistan for treatment of different ailments such as diarrhoea, diabetes, hepatitis, narcotic, coughing, fever, asthma, stomach, tonic, liver, abortification, rheumatism, laxative and other bacterial and fungal infections. However, detailed screening for such medicinal plants should be focused on discovering new pharmacological ingredients because few plants have been screened for their pharmacological and phytochemical belongings in Pakistan. Seeds, fruits and leaves were the most preferred parts in herbal remedies, as these comprise of extraordinary bioactive ingredients. Srithi et al. (2009) also documented that leaves, roots, tubers, seeds and fruits are the most favoured plant parts in the traditional medicines. The use of aerial parts such as leaves and flowers etc. for treatment of different ailments are harmless and sustainable (Giday et al., 2003). During the current study, it was discovered that aerial parts such as leaves, and shoots were used in most of the cases while gum was used in least. However, entire plant is not preferred to be used for ailment treatment because removal of plants will lead to plant species loss. Therefore, the use of aerial parts of plants as medicine is more suitable for sustainable management of medicinal flora (Ghimire et al., 2008). Awaad-Amani et al. (2006) screened the Alhagi maurorum for the ulcer due to its antiulcergenic properties. Likewise, Ismail (2007) conducted a detailed research on pharmacological and pharmacognostic investigations of Geranium wallichianum from the KP, Pakistan. Details of phytochemicals and anthelminthic activities of Chenopodium album has been assessed by different pharmacists and further work is being carried out (Jabbar et al., 2007. Antifungal and antibacterial activities of different extracts of Datura stramonium have also been assessed and it was found to be a potential plant from KP, Pakistan (Gul et al., 2012). Kusari et al. (2013) assessed Cannabis sativa for its potential effects against fungal and bacterial ailments and found best activities against targeted diseases. However, majority of medicinal plants of the present study area are not subjected to the detailed pharmacological screenings.

\section{Conclusions}

The present study emphasized on exploration and documentation of the indigenous knowledge of medicinal flora from the knowledgeable people of Swabi and Hazara regions of Pakistan. In district Swabi, 54 medicinal plant species were recorded at Razzar tehsil whereas 57 species were reported at Gadoon valley. Similarly, in Hazara region, 60 species were recorded at Allai valley and 50 medicinally important plant species were identified in Tanawal valley. Lack of attention towards medicinal plants and their traditional uses were found amongst young generation because of numerous reasons. The findings of this study clearly indicated that these areas need much attention for medicinal plants documentation, conservation and protection by the government, non-government organization and most local communities. The present study suggested that cultivation of high valued and most wanted medicinal plants is very essential. Trainings for awareness may be organised for the collectors of medicinal plants on cultivation, collection, processing and postharvest treatment. Harvesting of medicinal plants should be done at the right season. Local people should also be encouraged to participate in conservation and management of threatened and endangered medicinal plants to ensure their sustainability. Therefore, these medicinal plants should be focused for detail phytochemical and safety evaluations.

\section{References}

AHMAD, H., KHAN, S.M., GHAFOOR, S. and ALI, N., 2009a. Ethnobotanical study of upper Siran. Journal of Herbs, Spices E Medicinal Plants, vol. 15, no. 1, pp. 86-97.

AHMAD, M., KHAN, M.A., RASHID, U., ZAFAR, M., ARSHAD, M. and SULTANA, S., 2009b. Quality assurance of herbal drug valerian by chemotaxonomic markers. African Journal of Biotechnology, vol. 8, no. 6, pp. 1148-1154.

AHMAD, M., KHAN, M.A., ZAFAR, M., ARSHAD, M., SULTANA, S. and ABBASI, B.H., 2010. Use of chemotaxonomic markers for misidentified medicinal plants used in traditional medicines. Journal of Medicinal Plants Research, vol. 4, no. 13, pp. 1244-1252.

AHMAD, S.S. and HUSAIN, S.Z., 2008. Ethno medicinal survey of plants from salt range (Kallar Kahar) of Pakistan. Pakistan Journal of Botany, vol. 40, no. 3, pp. 1005-1011.

AJAIB, M., KHAN, Z., KHAN, N. and WAHAB, M., 2010. Ethnobotanical studies on useful shrubs of district Kotli, Azad Jammu \& Kashmir, Pakistan. Pakistan Journal of Botany, vol. 42, no. 3, pp. 1407-1415. 
AWAAD AMANI, A.S., MAITLAND, D.J. and SOLIMAN, G.A., 2006. Antiulcerogenic activity of Alhagi maurorum. Pharmaceutical Biology, vol. 44, no. 4, pp. 292-296.

AWAN, M.R., JAMAL, Z. and KHAN, A., 2013. Ethno-botanical studies of economically important plants from mountainous region of Gilgit-Baltistan, Pakistan. Science Technology and Development, vol. 32, no. 4, pp. 308-318.

BALICK, M.J. and COX, P.A., 1996. Plants, people, and culture: the science of ethnobotany. New York: Scientific American Library. https://doi.org/10.1017/S0376892997240142.

BHARDWAJ, S. and GAKHAR, S.K., 2005. Ethnomedicinal plants used by the tribals of Mizoram to cure cuts $\&$ wounds. Indian Journal of Traditional Knowledge, vol. 4, no. 1, pp. 75-80.

BIBI, S., HUSAIN, S.Z. and MALIK, R.N., 2008. Pollen analysis and heavy metals detection in honey samples from seven selected countries. Pakistan Journal of Botany, vol. 40, no. 2, pp. 507-516.

BUKHARI, A.H., 1994. Ethnobotanical survey and vegetation analysis of Machyara National Park Azad Kashmir, Pakistan. Pakistan: University of Azad Kashmir. M. Sc. Thesis.

CALIXTO, J.B., 2005. Twenty-five years of research on medicinal plants in Latin America: a personal view. Journal of Ethnopharmacology, vol.100, no. 1-2, pp. 131-134. http://dx.doi. org/10.1016/j.jep.2005.06.004. PMid:16006081.

COX, P.A., 2000. Will tribal knowledge survive the millennium? Science, vol. 287, no. 5450, pp. 44-45. http://dx.doi.org/10.1126/ science.287.5450.44. PMid:10644221.

DAR, M.E.U.I., 2003. Ethnobotanical uses of plants of Lawat District Muzaffarabad, Azad Jammu and Kashmir. Asian Journal of Plant Sciences, vol. 2, no. 9, pp. 680-682. http://dx.doi.org/10.3923/ ajps.2003.680.682.

DUBEY, S. and SAO, S., 2018. Antimicrobial activity of crude stem extracts of some medicinal plants against skin disease causing microbes from Chhattisgarh Region. International Journal of Engineering Technology Science and Research, vol. 5, pp. 2394-3386.

GHIMIRE, S.K., GIMENEZ, O., PRADEL, R., MCKEY, D. and AUMEERUDDY-THOMAS, Y., 2008. Demographic variation and population viability in a threatened Himalayan medicinal and aromatic herb Nardostachys grandiflora: matrix modelling of harvesting effects in two contrasting habitats. Journal of Applied Ecology, vol. 45, no. 1, pp. 41-51. http://dx.doi.org/10.1111/j.13652664.2007.01375.x.

GIDAY, M., ASFAW, Z., ELMQVIST, T. and WOLDU, Z., 2003. An ethnobotanical study of medicinal plants used by the Zay people in Ethiopia. Journal of Ethnopharmacology, vol. 85, no. 1, pp. 43-52.

GOVAERTS, R., 2001. How many species of seed plants are there? Taxonomy, vol. 50, no. 4, pp. 1085-1090. http://dx.doi. org/10.2307/1224723.

GUL, H., QAISRANI, R.N., KHAN, M.A., HASSAN, S. and YOUNIS, N., 2012. Antibacterial and antifungal activity of different extracts of Datura stramonium (branches and leaves sample). Journal of Biotechnology and Pharmaceutical Research, vol. 3, no. 9, pp. 141-148.

HOSTETTMANN, K., MARSTON, A., NDJOKO, K. and WOLFENDER, J.L., 2000. The potential of African plants as a source of drugs. Current Organic Chemistry, vol. 4, no. 10, pp. 973-1010. http:// dx.doi.org/10.2174/1385272003375923.

IBRAR, M., HUSSAIN, F. and SULTAN, A., 2007. Ethnobotanical studies on plant resources of Ranyal hills, District Shangla, Pakistan. Pakistan Journal of Botany, vol. 39, no. 2, pp. 329.

ISMAIL, M. 2007. Pharmacognostic and pharmacological investigations of Geranium Wallichianum D. Don Ex sweet. Peshawar, Pakistan: University of Peshawar. Doctoral dissertation.
JABBAR, A., ZAMAN, M.A., IQBAL, Z., YASEEN, M. and SHAMIM, A., 2007. Anthelmintic activity of Chenopodium album (L.) and Caesalpinia crista (L.) against trichostrongylid nematodes of sheep. Journal of Ethnopharmacology, vol. 114, no. 1, pp. 86-91.

KHAN, S.M., HARPER, D.M., PAGE, S. and AHMAD, H., 2011. Residual value analyses of the medicinal flora of the Western Himalayas: the Naran Valley, Pakistan. Pakistan Journal of Botany, vol. 43, pp. 97-104.

KONNO, B., 2004. Integration of traditional medicine with modern medicine. Addis Ababa: EHNRI, pp. 3-9.

KUSARI, P., KUSARI, S., SPITELLER, M. and KAYSER, O., 2013. Endophytic fungi harbored in Cannabis sativa L.: diversity and potential as biocontrol agents against host plant-specific phytopathogens. Fungal Diversity, vol. 60, no. 1, pp. 137-151.

MAHMOOD, A., MAHMOOD, A. and TABASSUM, A., 2011a. Ethnomedicinal survey of plants from District Sialkot, Pakistan. Journal of Applied Pharmacy, vol. 3, pp. 212-220. http://dx.doi. org/10.21065/19204159.3.212.

MAHMOOD, A., MAHMOOD, A., MALIK, R.N. and SHINWARI, Z.K., 2013. Indigenous knowledge of medicinal plants from Gujranwala district, Pakistan. Journal of Ethnopharmacology, vol. 148, no. 2, pp. 714-723.

MAHMOOD, A., MAHMOOD, A., SHAHEEN, H., QURESHI, R.A., SANGI, Y. and GILANI, S.A., 2011b. Ethno medicinal survey of plants from district Bhimber Azad Jammu and Kashmir, Pakistan. Journal of Medicinal Plants Research, vol. 5, no. 11, pp. 2348-2360.

MAHMOOD, A., QURESHI, R.A., MAHMOOD, A., SANGI, Y., SHAHEEN, H., AHMAD, I. and NAWAZ, Z., 2011c. Ethnobotanical survey of common medicinal plants used by people of district Mirpur, AJK, Pakistan. Journal of Medicinal Plants Research, vol. 5, no. 18, pp. 4493-4498.

MALIK, R.N., HUSAIN, S.Z. and NAZIR, I., 2010. Heavy metal contamination and accumulation in soil and wild plant species from industrial area of Islamabad, Pakistan. Pakistan Journal of Botany, vol. 42, no. 1, pp. 291-301.

NAVEED, S., KHATTAK, I. and MARWAT, K.B., 2019. Ethnomedicinal study of weeds in maize rice and tobacco fields of Tehsil Razzar district Swabi Pakistan. Pakistan Journal of Weed Science Research, vol. 25, no. 2, pp. 91-98.

PANHWAR, A.Q. and ABRO, H., 2007. Ethnobotanical studies of Mahal Kohistan (Khirthar national park). Pakistan Journal of Botany, vol. 39, no. 7, pp. 2301-2315.

PHILLIPS, O., GENTRY, A.H., REYNEL, C., WILKIN, P. and GÁLVEZDURAND, B.C., 1994. Quantitative ethnobotany and Amazonian conservation. Conservation Biology, vol. 8, no. 1, pp. 225-248. http://dx.doi.org/10.1046/j.1523-1739.1994.08010225.x.

PIE, M. and MANANDHARA, K., 1987. The percentage of medicinal wild species in Himalayan Ranges. Pakistan Journal of Botany, vol. 10, no. 6, pp. 65-74.

QURESHI, R.A., GHUFRAN, M.A., GILANI, S.A., SULTANA, K. and ASHRAF, M., 2007. Ethnobotanical studies of selected medicinal plants of sudhan gali and ganga chotti hills, district Bagh, Azad Kashmir. Pakistan Journal of Botany, vol. 39, no. 7, pp. 2275-2283.

RAJ, A. and TOPPO, P., 2014. Assessment of floral diversity in Dhamtari district of Chhattisgarh. Journal of Plant Development Sciences, vol. 6, no. 4, pp. 631-635.

RATES, S.M.K., 2001. Plants as source of drugs. Toxicon, vol. 39, no. 5, pp. 603-613. http://dx.doi.org/10.1016/S0041-0101(00)001549. PMid:11072038.

SAGHIR, I.A., AWAN, A.A. and MAJID, S., 2001. Ethnobotanical studies of Chikar and its Allied Areas of District Muzaffarabad. 
Online Journal of Biological Sciences, vol. 1, no. 12, pp. 1165-1170. http://dx.doi.org/10.3923/jbs.2001.1165.1170.

SARWAT, S.Z. and AHMAD, N., 2012. Screening of potential medicinal plants from district Swat specific for controlling women diseases. Pakistan Journal of Botany, vol. 44, no. 4, pp. 1193-1198.

SCHIPPMANN, U., LEAMAN, D.J. and CUNNINGHAM, A.B., 2002. Impact of cultivation and gathering of medicinal plants on biodiversity: global trends and issues. In: IX Regular Session of the Commission on Genetic Resources for Food and Agriculture. Biodiversity and the ecosystem approach in agriculture, forestry and fisheries. 12-13 October 2002, Rome. Rome, Italy: FAO, pp. 143-167.

SHEHZAD, K.R. and QURESHI, R.A., 2001. Common ethnomedicinal uses of plants in Jatlan area, district Mirpur, Azad Jammu and Kashmir, Pakistan. Pakistan: Hamdard Medicus, pp. 42-45.

SHENG-JI, P., 2001. Ethnobotanical approaches of traditional medicine studies: some experiences from Asia. Pharmaceutical Biology, vol. 39, Suppl. 1, pp. 74-79. PMid:21554174.

SHINWARI, Z.K. and GILANI, S.S., 2003. Sustainable harvest of medicinal plants at Bulashbar Nullah, Astore (northern Pakistan). Journal of Ethnopharmacology, vol. 84, no. 2-3, pp. 289-298. http://dx.doi.org/10.1016/S0378-8741(02)00333-1. PMid:12648828.

SHINWARI, Z.K., 2010. Medicinal plants research in Pakistan. Journal of Medicinal Plants Research, vol. 4, no. 3, pp. 161-176.
SRITHI, K., BALSLEV, H., WANGPAKAPATTANAWONG, P., SRISANGA, P. and TRISONTHI, C., 2009. Medicinal plant knowledge and its erosion among the Mien (Yao) in northern Thailand. Journal of Ethnopharmacology, vol. 123, no. 2, pp. 335-342. http://dx.doi. org/10.1016/j.jep.2009.02.035. PMid:19429381.

ULLAH, M., KHAN, M.U., MAHMOOD, A., MALIK, R.N., HUSSAIN, M., WAZIR, S.M., DAUD, M. and SHINWARI, Z.K., 2013. An ethnobotanical survey of indigenous medicinal plants in Wana district south Waziristan agency, Pakistan. Journal of Ethnopharmacology, vol. 150, no. 3, pp. 918-924. http://dx.doi. org/10.1016/j.jep.2013.09.032. PMid:24120747.

ULLAH, R., NABI, G., KHAN, N., KHAN, A., KHAN, B.A., ULLAH, R. and IMTIAZ KHAN, K.J.A.J., 2019. Performance of potato varieties under the climatic conditions of Abbottabad Hazara. Pure and Applied Biology, vol. 8, no. 2, pp. 1744-1756. http://dx.doi. org/10.19045/bspab.2019.80118.

VANDEBROEK, I. and THOMAS, E., 2003. Plantas medicinales para la atencion' primaria de la salud: el conocimiento de ocho medicos' tradicionales de Apillapampa (Bolivia). Cochabamba, Bolivia: Industrias Graficas' Serrano.

WORLD HEALTH ORGANIZATION, 2002. Traditional medicine: growing needs and potential. Geneva: World Health Organization.

ZANDIAL, R., 1994. Ethno botanical studies and population analysis of Machyara National Park Azad Kashmir. Pakistan: University of Azad Kashmir, Doctoral dissertation. 